Dimorphism in Two New Genera of Devonian Tabulate Corals

GEOLOGICALSURVEY PROFESSIONALPAPER 743-D

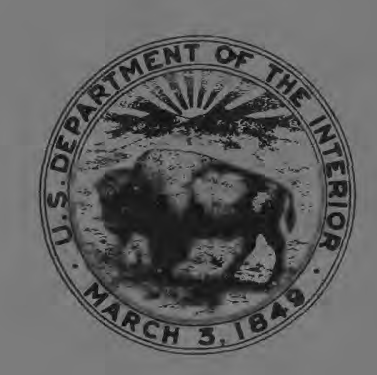




\section{Dimorphism in Two New Genera of Devonian Tabulate Corals}

By WILLIAM A. OLIVER, JR.

G O N T R B U T I O N T O PALEON T OL OG Y

GEOLOGICAL SURVEY PROFESSIONAL PAPER 743-D

Analysis of dimorphism, growth and

development, and wall microstructure

in new coral genera from New York

and Kentucky

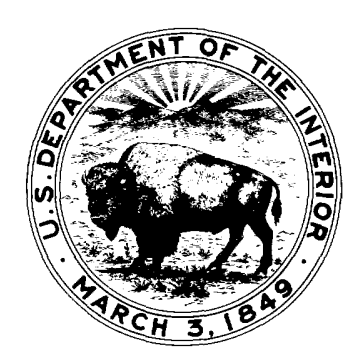

\begin{tabular}{llllll}
\hline UNITED & STATES & GOVERNMENT & PRINTING & OFFICE, & WASHINGTON $: 1975$
\end{tabular} 


\section{UNITED STATES DEPARTMENT OF THE INTERIOR \\ STANLEY K. HATHAWAY, Secretary}

\section{GEOLOGICAL SURVEY}

V. E. McKelvey, Director

\section{Library of Congress Cataloging in Publication Data}

Oliver, William Albert, 1926-

Dimorphism in two new genera of Devonian tabulate corals.

(Contributions to paleontology) (Geological Survey professional paper ; 743-D)

Bibliography: p.

Includes index.

Supt. of Docs. no.: I 19.16:743-D

1. Tabulata. 2. Paleontology-Devonian. 3. Paleontology-North America. I. Title. II. Series. III. Series: United States. Geological Survey. Professional paper ; 743-D.

QE778.042 563'.6 75-619109

For sale by the Superintendent of Documents, U.S. Government Printing Office

Washington, D.C. 20402

Stock Number 024-001-02647-3 


\section{CONTENTS}

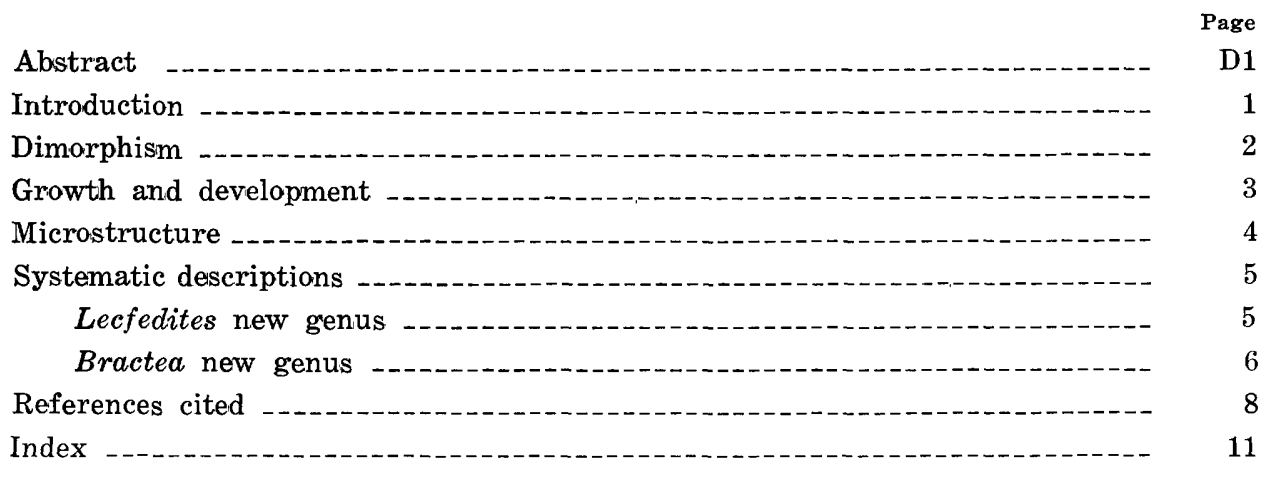

\section{ILLUSTRATIONS}

[Plates follow index]

PLATE 1. Lecfedites canadensis (Billings), Bractea arbor (Davis), and B. frutex (Davis).

2-4. Lecfedites canadensis (Billings).

5. Bractea arbor (Davis) and B. frutex (Davis).

6, 7. Bractea arbor (Davis). 



\title{
DIMORPHISM IN TWO NEW GENERA OF DEVONIAN TABULATE CORALS
}

\author{
By William A. Oliver, Jr.
}

\begin{abstract}
"Dimorphism" in most tabulate corals consists of a bimodal distribution of corallite diameters; this can better be termed "dimetrism." Demonstration of a morphologic difference, other than size, between forms has been rare. "Favosites" canadensis (Billings) has two kinds of corallites -large ones with squamulae and small ones with normal, complete tabulae. "Favosites" arbor Davis also has two kinds of corallites-one with a deep calice and possibly two distinct ontogenetic stages and a second that is smaller, having a shallow calice and possibly only the second ontogenetic stage.

Dimorphism, corallite ontogeny, and microstructure are emphasized in descriptions of the species and two new genera: Lecfedites (type species $F$. canadensis) and Bractea (type species $F$. arbor). The genera are known only from rocks of Emsian and Eifelian ages in the Eastern North American Biogeographical Province.
\end{abstract}

\section{INTRODUCTION}

Dimorphism has been claimed for many species of Favosites and other favositids (for example, Stumm, 1965 , p. 60-67; Fenton and Fenton, 1936, p. 19) but has not been described in detail in these forms, and its possible significance has seldom been discussed. Among favositids exhibiting dimorphism, "Favosites" canadensis (Billings) stands out as the ultimate example because this species shows marked contrast between large round corallites and small angular ones. No other favositoid species is so strikingly dimorphic, and it has been argued that other claimed examples are not dimorphic at all (Sokolov, 1955, p. 136). In most cases the claim for dimorphism has been based on bimodal diameter distribution (dimetrism), but this is far more often stated than demonstrated and, in any case, additional morphologic differences are needed before significant polyp differentiation can be assumed.

"Favosites" canadensis has two kinds of corallites that differ in internal morphology as well as in size. This species is not a Favosites and is here made the type of Lecfedites new genus. " $F$." arbor Davis is superficially like $L$. canadensis and the two have commonly been either synonymized or separated on the basis of growth form only. Actually, they are very different in internal structure and " $F$." arbor corallites are differentiated from each other only in size, in calice characters, and possibly in some aspects of ontogeny. The species is here made the type of Bractea new genus.

In this paper I place the discussions of dimorphism, ontogeny, and microstructure in $L$. canadensis and $B$. arbor before the formal systematic descriptions because I consider these to be of general interest. It should be clear that the nature of dimorphism, the growth pattern, and the microstructure are fundamental to my concepts of the new genera.

Acknowledgments.- Type specimens were loaned to me by the Museum of Comparative Zoology, Harvard University, and the Geological Survey of Canada, Ottawa. I thank B. Kummel and T. E. Bolton of those organizations for their cooperation. All thin sections were prepared in my laboratory by W. C. Pinckney, Jr. Photographic work was by W. C. Pinckney, Jr., H. E. Mochizuki, and R. H. McKinney.

Depositories and catalogues are abbreviated as follows :

GSC, Geological Survey of Canada, Ottawa

MCZ, Museum of Comparative Zoology, Harvard University

USGS-SD, U.S. Geological Survey, SilurianDevonian catalog, Washington

USNM, U.S. National Museum of Natural History, Washington 


\section{DIMORPHISM}

Lecfedites canadensis. - Two kinds of corallites in Lecfedites canadensis are designated types A and B for convenience. They differ significantly in morphology as well as in size, and it seems probable that they were formed by distinct polyps although no functional difference can be demonstrated.

On the upper surfaces of well preserved coralla, large (type A) corallites are round, with the wall forming a low ridge above the general corallum surface (pl. 1, figs. 1-4, 8) ; lumen diameters are commonly 0.8 to $1.0 \mathrm{~mm}$. Type $B$ corallites are small and angular although the lumen is rounded by wall thickening; lumen diameters are commonly 0.3 to $0.5 \mathrm{~mm}$. In transverse thin sections (at right angles to mature parts of corallites), the A-B differences are less obvious because of a few large $B$ types, but the size and shape differences identify most corallites with little question (pl. 2, fig. 5). In longitudinal sections the differences are again clear (pl. 2, figs. 1, 2,6). Type A corallites have squamulae and some tabulae, collectively rather closely spaced. B corallites lack squamulae but have relatively widely spaced, complete tabulae.

Both A and B corallites have mural pores and neither have septa or septal spines. Wall structure is identical in the two types-favositoid in the early stage, thickened and trabecular in the late stage. The morphology of each corallite type is similar to that known in other corals and interpretation of the type B corallites as coenenchyme (as in the Heliolitoidea) is untenable (Lindström, 1899, p. 48-50).

I assume that both types of corallites were formed by individual polyps occupying the calices at the surface of the corallum. The pronounced differences in corallite morphology suggest that the polyps were morphologically and probably functionally different also, but I see no basis for suggesting what function (s) the two types of polyps performed.

Bractea arbor.-The surfaces of Bractea arbor colonies are superficially like those of $L$. canadensis; a limited number of relatively large (type A) corallites have rounded, slightly projecting calice margins in contrast to smaller polygonal (type B) corallites that separate the larger ones (pl. 1, figs. $5-7)$. The B corallites have shallow, broadly Vshaped calices with a very small orifice at the bottom of the $\mathrm{V}$; corallites commonly have diameters of 0.5 to $0.8 \mathrm{~mm}$, and orifice diameters from 0.1 to $0.3 \mathrm{~mm}$. The A corallites have deeper calices with steep walls and with prominent squamulae forming incomplete bottoms ; corallites commonly have diameters of 1.0 to $1.5 \mathrm{~mm}$, and orifice diameters of 0.5 $\mathrm{mm}$ or more. In many A corallites, 12 spinelike squamulae project from the wall and are easily visible with low-power magnification. These surface features are emphasized here because the A-B differences are not apparent in sections.

In tangential thin sections (at right angles to corallites near surfaces of coralla), the boundaries of all corallites are polygonal and size variation appears to be continuous rather than bimodal (pl. 7). The morphology of large and small corallites in all stages of development and in all kinds of sections is similar, and no dimorphism is apparent. All corallites have numerous squamulae and mural pores.

A kind of differentiation in ontogeny does exist, however, as discussed in the following section on growth. Some corallites (type A?) originate in an inner, thin-walled zone, reach their full diameter at the margin of that zone, and are constant in size through an outer, thick-walled zone. Other corallites (type B?) originate in the outer zone and have no thin-walled stage. The small corallites on the corallum surface are more likely to have originated in the outer zone and the larger ones in the inner zone, but I have not been able to demonstrate that this is consistent, although it does adequately explain the size variation noted in tangential sections. In any case, dimorphism in $B$. arbor is fundamentally different from that in $L$. canadensis.

Discussion.-Dimorphism in zoantharian corals is extremely rare, although it is common in alcyonarians and other colonial coelenterates. Sokolov (1955, p. 136) discussed "dimorphism in tabulates" and argued that there is none. He grouped "dimorphic" species in two categories: one in which there is a size differentiation at the surface of the colony but no other morphologic differences, and another in which the smaller "corallites" could be shown to be tubes of "commensal worms."

Forms displaying simple size differentiation were termed "dimetric" and attributed to growth differences by Ross (1953). In one particular species of Favosites she noted, "The dimetrism *** appears to be related to crowding of corallites, so that some attain the adult size of the species while others do not. The larger corallites usually project slightly above the surrounding smaller corallites, suggesting that they were growing faster and may have had an advantage over surrounding corallites." (p. 71). Sokolov attributed the size differences to growth stage (that is, ontogeny), noting that the earlier stages of large corallites were identical to the smaller corallites. Either explanation would explain continuous variation, but both must assume some 
kind of threshold to be acceptable as an explanation of discontinuous variation. Ross' explanation implies an ecologic threshold so that "unsuccessful" polyps would remain significantly smaller than the large, "successful" ones; Sokolov's implies a growth "spurt" during ontogeny. In any case, in dimetric favositoids, some factor, either genetic or environmental, determined that some few corallites would be large relative to all others.

Dimorphism in both $L$. canadensis and $B$. arbor involves more than bimodal size distribution (dimetrism). It is probable that the structural differentiation of these forms represents a functional differentiation of the polyps, but the nature of this specialization is not known.

Oliver (1966) described colonies of the tabulate coral Striatopora having a clear dimorphism that, in part, could be related to function. Bractea arbor dimorphism may be analagous, but it is more difficult to analyze because of larger numbers of smaller corallites. As far as I know, B. arbor and Lecfedites canadensis are only the second and third favositoid tabulates in which true dimorphism has been described. Coates and Oliver (1973, p. 20-21) discussed a few other possible examples of dimorphism within zoantharian corals (halysitids and one scleractinian) but even possible examples are scarce.

\section{GROWTH AND DEVELOPMENT}

Lecfedites canadensis.-Two distinct ontogenetic stages are present in both types of $L$. canadensis corallites. The morphologic change produces a zonal appearance in colonies. For convenience in discussion the stages and zones are numbered 1 and 2 , but the zones should not be mistaken for astogenetic stages, which do not exist in this species.

The protocorallite has not been recognized in any specimen, but initial growth of early-stage corallites was parallel to the substrate, commonly more-or-less horizontal. A thin holotheca was deposited as the colony base, sometimes on shells or shell fragments but commonly directly on the lime-mud-to-sand substrate. After initial reptant growth, polyps gradually turned upward through a $90^{\circ}$ angle and corallites became parallel and approximately vertical.

Essentially all corallite expansion and most increase took place during the reptant stage (stage 1). By the time the corallites became vertical (stage 2 ), they had reached their full diameter; I have not seen any indication of offsets in stage 2 except in cases of colony rejuvenation. Normal increase continued at the margin of the colony long after early (central) corallites were growing upward, and colony diameters of $25 \mathrm{~cm}$ or more are common. Length of stage 1 corallites varies from 1 to $5 \mathrm{~mm}$ or more.

Stage 1 corallites are vaulted in cross section ( $\mathrm{pl}$. 3 , fig. 4), forming two or three layers above the holotheca. Increase is peripheral, commonly with a single offset appearing on the underside of the parent corallite during stage 1 ; thus, in any section through stage 1 the youngest corallites tend to be at the bottom. Some corallites certainly produced two or more offsets, but most seem to have produced only one. Both $\mathrm{A}$ and $\mathrm{B}$ corallites were capable of producing either type of corallite in stage 1 , and examples of all four possible parent-offset combinations have been seen in the study material.

Size differentiation of type $A$ and $B$ corallites began in stage 1 , but the general morphology of the two types is similar. Complete tabulae and mural pores are present in all corallites. Squamulae may or may not appear in type $A$ individuals near the end of stage 1. Microstructure is favositoid with a distinct dark line (axial plane) in the wall and, on either side, light-colored tissue composed of fibers at right angles to the axial plane (radial-fibrousfavositoid structure of Dubatolov, 1969, 1971, and Oekentorp, 1972).

The general geometry of stage 1 is like that diagrammed for Favosites hisingeri Group II by Tripp (1933, p. 84-85, fig. 13, pl. 13, fig. 2b) and may be typical of broadly expanding favositoid colonies.

Stage 2 corallites are erect (growing at right angles to holotheca and substrate) and equidimensional in cross section. Diameter changes are commonly insignificant, but there are some exceptions to this. Differentiation of type A and B corallites was established by type A being characterized by large size, numerous squamulae, and few tabulae; type $B$ corallites are small in diameter, have complete tabulae, and lack squamulae (pls. 2, 3, and 4).

With continued corallite growth, the walls thickened markedly and apparent wall microstructure changed. Corallites in ontogenetic stage 2 have thick walls composed of columnar units (trabeculae) with no, or only faint, traces of an axial plane (paratrabecular structure of Dubatolov and Oekentorp) ; the lumena are circular or rounded in cross section, and differentiation of type $\mathrm{A}$ and $\mathrm{B}$ corallites is complete.

Increase during stage 2 apparently took place only as a result of accident. If a part of the colony was damaged or smothered by mud, new offsets were produced by adjacent stage 2 individuals. These 
grew over the affected area forming a holotheca and starting a new stage 1-stage 2 sequence. Similarly, new lateral expansions of the colony could be initiated by stage 2 individuals apparently as a result of a change in bounding conditions.

Although stage 2 corallites are normally erect, parallel, and constant in diameter, there are several examples of diameter decrease with upward growth (pl. 3, figs. 1, 3, 4). This apparently results in a greater decrease in surface area for a part of the colony than can be explained by the lumen diameter decrease seen in the sections. Additional compensation seems to be through decrease in wall thickness and the elimination of some corallites. In some sections, type A corallites seem to convert to type B with some decrease in diameter, but they remain larger than other type B's (pl. 3, fig. 4). In other examples, type A corallites are apparently unaffected and all compensation seems to have been in type $B$ individuals.

Bractea arbor.-Growth and development in Bractea arbor colonies are like those of Lecfedites canadensis colonies but with modifications for a ramose growth habit (pls. 5 and 6). Stage 1 corallites are in the axial zone of the colony and are parallel to or at a low angle to the axis of the branch; microstructure is radial-fibrous-favositoid. Stage 2 corallites are perpendicular to the axis and surface of the branch; wall microstructure is paratrabecular. Corallite expansion takes place primarily in the inner, thin-walled zone; corallites in the outer zone that originated in the inner zone are constant in diameter. Increase is common in the axial zone (stage 1 corallites) where peripheral offsets commonly are on the axial side of the parent corallite. Increase in the outer zone of the colony (stage 2 corallites) was certainly common also (because of space-filling requirements) but is difficult to see in thin section because of the very thick walls (pls. 5, 6). Corallites that can be followed through the outer zone are constant in diameter. The apparent size difference noted on the growing surface of the colony is possibly the difference between corallites that went through stage 1 and 2 and those that developed in stage 2 only.

The general growth geometry of $B$. arbor corallites and coralla is similar to that known in other ramose cerioid tabulates.

\section{MICROSTRUCTURE}

The wall structure in $L$. canadensis and $B$. arbor is similar and has been described for other genera.
The stage 1 structure in both is similar to that of Favosites. In section, walls are double with a dark line or plane separating the light fibrous walls of adjacent corallites. The nature of the dark plane is unclear, but it may be formed by the irregular junction of the opposing fibers rather than as a separate element (third layer in wall). The fibers of the light layers are perpendicular to the dark plane or are inclined slightly toward the distal (calice) end of the corallite. This is the "radial-fibrous-favositoid" structure of Dubatolov $(1969$, p. $42 ; 1971$, p. $30-31$; see also Oekentorp, 1972, p. 60-61).

The stage 2 wall structure is less familiar but has recently been described in several genera and termed "paratrabecular" by Tong-dzuy (1966, p. 24 ; see also Dubatolov, 1969, 1971, and Oekentorp, 1972). Walls are composed of parallel, columnar units that appear to be single, monacanthine trabeculae.

In transverse sections of stage 2 walls, a discontinuous center line or plane is apparent in well preserved specimens of $B$. arbor but is apparently lacking in $L$. canadensis. Thus, the walls appear to be two-columns thick in the former and one-column thick in the latter. In L. canadensis the columns are approximately 0.1 by $0.15-0.2 \mathrm{~mm}$ in cross section, the long dimension being perpendicular to the wall; the wall around type A corallites commonly consists of some 20 to 40 columns (pl. 4, figs. 1, 7), although as few as 16 were noted in one example, possibly because of recrystallization. In $B$. arbor the columns are much larger (pl. 7, figs. 4, 7), and commonly the wall around type A corallites consists of 12 columns.

In longitudinal sections of well preserved individuals, the columnar structure is evident (pl. 4, fig. 6 and others), and observed dimensions are consistent with those measured in transverse sections. Well preserved columns have trabecular structure and the columns or trabeculae appear to result from the breakup of the initial favositid wall, much as suggested by Flower (1961, p. 26-28) for some Ordovician corals. If so, $L$. canadensis represents a more advanced stage (with only remnants of the wall mid-plane and distinct trabeculae) than does $B$. arbor (with distinct if discontinuous mid-planes).

Oekentorp (1972) considered both types of microstructure to be secondary, and certainly some of the observed variation is due to post-mortem alteration. However, it seems likely that the basic patterns are real and that the ontogenetic change from radialfibrous to paratrabecular is significant. I consider both the microstructures and the ontogenetic change to be important generic-level characters. 


\section{SYSTEMATIC DESCRIPTIONS}

Genus LECFEDITES new genus

Type species.-Fistulipora canadensis Billings, 1858a, p. 165-166; first illustrated 1859, p. 98, fig. 1 . "Corniferous or Onondaga limestone; lot 6, con. 1, Township of Wainfleet," southwestern Ontario. This could be either the Bois Blanc Formation or the lower Onondaga Limestone, but the specimen is probably from the Edgecliff Member of the Onondaga. The locality is 3 miles $(5 \mathrm{~km})$ west of the Welland Canal in Port Colborne and between Provincial highway 5 and Lake Erie. The locality area includes an abandoned quarry in the bioherm facies of the Edgecliff Member, and it is probable that the type specimen came from there.

Diagnosis.-Massive or laminated, cerioid tabulate corals with two kinds of corallites: type A corallites are large, have more rounded cross sections, contain closely spaced squamulae with supplemental tabulae, and have protruding calice rims; type $B$ corallites have less than one-half the diameter of the large ones, are more polygonal (angular) in section, and have simple, widely spaced, complete tabulae. All corallites have mural pores and lack septa and septal spines. Ontogenetic stages in both types of corallites are (1) reptant with vaulted growth form and thin walls with radial-fibrous-favositid microstructure becoming (2) erect with thickened walls of paratrabecular microstructure.

Description.-The important characters of the genus are described in the previous sections entitled "Dimorphism," "Growth and development," and "Microstructure." Additional information is included in the following discussion and species description.

Discussion.-My description of Lecfedites n. gen. is based entirely on the type species, $L$. canadensis (Billings). Most modern specialists have assigned L. canadensis to Favosites, but early interpretations are instructive in understanding the morphology and possible relationships of the genus. Billings (1858a and b, 1859, 1863) assigned the species to Fistulipora because of the dimorphic appearance. Rominger $(1862,1876)$ considered it a Favosites (as Calamopora in 1862) because of the tabulae and mural pores, and was the first to note that the squamulae were limited to the larger corallites. Rominger's descriptions, however, were based on a mixed lot of L. canadensis and Bractea arbor (Davis), and the "twelve distinct longitudinal ridges ..." (Rominger, 1862, p. 397) are a character of the latter but not the former species.
Nicholson (1874) agreed with Billings' assignment but considered the smaller tubes to be coenenchyme. Later, however, he accepted Rominger's argument (Nicholson 1879, p. 44 and $289 ; 1881$, p. $94)$ and assigned the species to Favosites. Rominger and Nicholson (works cited above) and Quenstedt (1881, p. 29-30) cited other species of Favosites as intermediate between $L$. canadensis and normal, monomorphic species. Lindström (1899, p. 48-49) compared L. canadensis to Heliolites and emphasized that in the former, "there is nothing that could be interpreted as coenenchyma" (p. 49). Fenton and Fenton (1936, p. 19-20) used $F$. canadensis to argue a link between favositids and the living Heliopora (again emphasizing the dimorphism).

Sokolov (1952, p. 51; 1955, p. 136, 159, pl. 6, figs. 5-7) referred $L$. canadensis to the genus Oculipora Sokolov, which was defined mainly on the basis of dimorphic corallites. The type species of Oculipora has complete tabulae, septal spines, and relatively thin walls; corallites do not show significant ontogenetic change, and there is no apparent corallite differentiation other than in size.

Ross $(1953$, p. 68 ) suggested that " $F$." canadensis was a possible ancestor of her Favosites placenta lineage. "The large corallites of $F$. canadensis have an internal structure which duplicates that of $F$. nitella centerfieldensis; the small corallites have horizontal, straight tabulae and lack squamulae, like $F$. placenta. Thus characters of two branches of the placenta lineage, one squamulate, the other dominantly non-squamulate, are combined in $F$. canadensis." (Ross, 1953, p. 68). (Swann, [1947, p. 244] had earlier referred to "the Favosites canadensisplacenta lineage" but without further explanation or description.)

The microstructure and mural pores of Lecfedites clearly separate it from Fistulipora (a bryozoan) and the heliolitoidids, as noted by Rominger and several other workers. It is only superficially similar to Oculipora. It is readily separable from Favosites but is probably derived from, and most closely related to, the Favositidae. A logical sequence would be from a normal Favosites, to a dimetric one, to Lecfedites - the final step reflecting functional specialization of polyps that initially were only different in size. This evolution took place within the Eastern North American Biogeographic Province at a time of maximum endemism of associated rugose corals (Oliver, 1973; 1974, in press).

In my opinion, the principal characters of Lecfedites are the distinct dimorphism and the ontogenetic change in wall thickness and microstructure. 
Each type of corallite in each of its two growth stages is known in other favositoid genera (for example, Favosites, Emmonsia, Echyropora, and Xenoemmonsia), but the combination is apparently unique.

Oekentorp (1972, p. 60) noted the paratrabecular wall in Riphaeolites Yanet, Echyropora Tong-dzuy, and Xenoemmonsia Leleshus. Riphaeolites is similar to Lecfedites in growth form and ontogeny and has the same succession of microstructures, but it has only one kind of corallite and lacks squamulae. Echyropora forms massive branches but shows the same succession of microstructures; it too is monomorphic and lacks squamulae. The structure of Xenoemmonsia is less clear, but it is monomorphic with squamulae in all corallites.

Distribution.-Known only in rocks of middle and early late Onesquethaw Age (Emsian-early Eifelian) in the Eastern North American Biogeographic Province.

Lecfedites canadensis (Billings)

Plate 1, figures 1-4, 8; plates 2-4

1858a Fistulipora Canadensis Billings, p. 165-166.

1858b F. Canadensis. Billings, p. 420.

$1859 F$. Canadensis. Billings, p. 98, fig. 1 (p. 2 in reprint edition).

1862 [part] Calamopora Canadensis (Billings). Rominger, p. 397.

1863 Fistulipora Canadensis. Billings, p. 364, fig. 358.

1874 [part] $F$. Canadensis Billings. Nicholson, p. 63 (excluding Hamilton forms).

1876 [part] Favosites canadensis (Billings). Rominger, p. 30-31, pl. 8, fig. 4 (not pl. 15, fig. 3).

$1881 F$. canadensis. Quenstedt, p. 29-30, pl. 144, fig. 8.

1887 [part?] Favosites canadensis. Davis, pl. 29, figs. 1, 2 (?pl. 29, fig. 3, specimen not seen).

1899 Favosites canadensis (Billings). Lambe, p. 12.

1899 F. canadensis (Billings). Lindstrom, p. 48-49 (discussion), pl. 2, figs. 23-27.

$1949 \quad F$. canadensis (Billings). Stumm, card 236.

1952 Oculipora canadensis (Billings). Sokolov, p. 51.

1955 O. canadensis (Billings). Sokolov, pl. 6, figs. 5-7.

Type specimen.-Three specimens in the collections of the Geological Survey of Canada (GSC $3387, a, b)$ are considered to be syntypes of Billings, although none is certainly the specimen illustrated in 1859 ( $3387 \mathrm{~b}$ may be the illustrated specimen). Stumm, 1949, stated: "Holotype no. 3387." Since this is the best of the three specimens, I accept it as lectotype (here pl. 1, figs. 1,2).

Diagnosis.-As for the genus.

Description.-The following details can be added to the generic description and the descriptions of dimorphism, growth, and microstructure. Lumen diameters measured in thin sections parallel and close to the surface of the colonies are: type $A, 0.60$ to $1.00 \mathrm{~mm}$; type $\mathrm{B}, 0.20$ to $0.48 \mathrm{~mm}$. Wall thickness varies from 0.10 (early stage 1) to $0.32 \mathrm{~mm}$ or more (late stage 2); commonly the wall around type A corallites is thicker than the wall between two type B corallites. Observed mural pores have diameters up to $0.13 \mathrm{~mm}$.

The squamulae (limited to type $A$ corallites) are large and very irregular (see illustrations), but commonly they are spoon-shaped with a concave distal surface. The tabulae in type $B$ corallites are mostly complete and distally concave, but some are horizontal or even convex.

Distribution.-Common in the Edgecliff Member of the Onondaga Limestone in New York and southwestern Ontario (early late Onesquethaw Age, early Eifelian). Rare in Bois Blanc Formation, southwestern Ontario (middle Onesquethaw Age, late Emsian) and in the Jeffersonville Limestone, Coral Zone, Falls of the Ohio, near Louisville, Ky. (middle and ?early late Onesquethaw Age).

Material studied.-Lectotype, GSC 3387; paralectotypes, GSC 3387a, 3387b, all probably from the Edgecliff Member of the Onondaga Limestone at Port Colborne, Ontario (see discussion of type species of Lecfedites $n$. gen.). Illustrated specimens: USNM 189922-927, from the bioherm facies of the Edgecliff Member, Onondaga Limestone, Old Fogelsanger quarry, Williamsville (near Buffalo), N.Y.; USNM 189928, from the lower foot of the Jeffersonville Limestone, Falls of the Ohio, Louisville, Ky.; MCZ 8518, Jeffersonville Limestone, Falls of the Ohio. Other sectioned material: eight specimens from Edgecliff Member, Williamsville, N.Y. (same location as above); one specimen from Edgecliff Member, Falls of Sandusk Creek, Walpole Township, Ontario; one specimen from Edgecliff Member or Bois Blanc Formation, at Port Colborne, Ontario; one specimen from Bois Blanc Formation at Hagarsville, Ontario.

Numerous additional specimens from Williamsville, N.Y., and the Falls of the Ohio are in the USNM collections.

\section{Genus BRACTEA new genns}

Type species.-Favosites arbor Davis, 1887, pl. 22, fig. 1; pl. 23, fig. 1. Jeffersonville Limestone, Falls of the Ohio, Louisville, Ky. (probably the lower part of the coral zone, Schoharie equivalent, middle Onesquethaw Age, Emsian).

Diagnosis.-Branching or massive, cerioid favositoid corals with relatively thin radial-fibrous- 
favositid wall in region of immature corallite growth and thick, paratrabecular wall in mature region. Squamulae are abundant and mural pores are common throughout the corallum. Corallites vary widely in diameter at surface of colony and are dimorphic; internally, the only apparent morphologic differentiation is in the presence of a thinwalled early stage; size separation is difficult. Increase is peripheral.

Discussion.-The generic diagnosis is based on the type species, which is described below. It differs from other described favositoids in combining the favositid-becoming-paratrabecular wall with squamulae in a cerioid-ramose growth form. It is very similar to Echyropora Tong-dzuy in growth form, wall microstructure, and corallite ontogeny, but Echyropora has normal, complete tabulae instead of squamulae. Xenoemmonsia Leleshus has paratrabecular wall structure and squamulae but lacks the favositid early corallite ontogeny. Riphaeolites Yanet and Lecfedites $\mathrm{n}$. gen. have similar corallite ontogeny and wall microstructure, but the former lacks squamulae, and the latter is dimorphic and lacks squamulae in one type of corallite.

Species assigned.-Two of Davis' species, in addition to the type species, are assigned to Bractea. Both are presently known only from the type specimens of Davis. They are briefly noted below with emphasis on apparent differences. Analysis of larger collections may show any two or all of the species to be synonyms.

Davis (his written note in his own copy of Davis, 1887) indicated all three of his species to be from the lower $6 \mathrm{ft}(1.8 \mathrm{~m})$ of the Jeffersonville Limestone at the Falls of the Ohio. This would include the lower coral zone (Schoharie equivalent, Emsian age) and the basal part of the upper coral zone (lower Onondaga equivalent, early Eifelian age). I have found $B$. arbor only in the lower (Schoharie age) unit and have not found the other species at all.

Distribution.-Known only in rocks of middle (and ?early late) Onesquethaw Age (Emsian and ?early Eifelian) in the Eastern North American Biogeographic Province.

\section{Bractea arbor (Davis)}

1876 [part] Favosites canadensis of Rominger (not Billings), p. 30-31, including specimens "with twelve distinct longitudinal ridges"; ?pl. 15, fig. 3 (specimen not seen).

$1887 \quad F$. arbor Davis, pl. 22, fig. 1; pl. 23, fig. 1.

$1949 \quad F$. arbor Davis. Stumm, cards 222-223.

1965 [part] $F$. arbor Davis. Stumm, p. 60-61, pl. 59, figs. $3,4,6,7$; ?not figs. 1, 2, 5, 8 and part of synonymy.
Type specimens.-Syntypes, MCZ 8496 (seven coralla fragments were studied but neither of the specimens illustrated by Davis was found) ; lectotype, here selected, MCZ 8496a (pl. 1, fig. 5; pl. 5, figs. 1-4). See genus discussion for locality and horizon of types.

Diagnosis.-As for the genus.

Description.-Coralla are cerioid, commonly ramose with branches ranging in diameter from 25 $\mathrm{mm}$ or less to $85 \mathrm{~mm}$ or more, rarely irregularly massive. Corallites open at right angles to the surface of the corallum. Corallite diameters measured in tangential sections near the surface of the colony vary from 0.5 to $1.5 \mathrm{~mm}$; lumen diameters vary from 0.1 to $0.9 \mathrm{~mm}$. Wall thickness varies greatly and many corallites are completely filled (pl. 7, fig. 6 ). The squamulae are large and coarse, and are related to the wall columns (trabeculae) in such a way that in transverse sections of corallites some columns seem to extend into the lumen. This is presumably the basis for Rominger's statement that "the larger tubes are always lined with a cycle of twelve rows of horizontal squamulae" (1876, p. 31).

In the inner thin-walled zone, corallite diameters up to $1.2 \mathrm{~mm}$ or more are common; squamulae are abundant in this zone but complete tabulae are also common (pl. 5, fig. 1; pl. 6, fig. 2).

Distribution.-Known only from the lower part of the Jeffersonville Limestone at the Falls of the Ohio, Louisville, Ky. Possibly limited to the lower coral zone of middle Onesquethaw Age (Schoharie equivalent; Emsian).

Material.-In addition to the primary types listed above, the following specimens were studied: illustrated specimen, USNM 189929 (colln. USGS 4721SD) ; nine additional sectioned specimens, USNM 17030 (three), 52861 (one), and USGS 4723-SD (two), and 5932-SD (three). All specimens are from the Jeffersonville Limestone at the Falls of the Ohio, Louisville, Ky.; specimens with USGS collection numbers are from the lower $4 \mathrm{ft}(1.2 \mathrm{~m})$ of the formation, middle Onesquethaw Age (Emsian; Bois Blanc or Schoharie equivalent); all other known specimens may be from the same stratigraphic interval.

Bractea frutex (Davis)

Plate 1, figures 9,10 ; plate 5 , figures 5, 6

1887 Favosites frutex Davis, pl. 24, figs. 1, 2.

$1949 \quad F$. frutex Davis. Stumm, card 257.

1965 [part?] $F$. arbor of Stumm (not Davis), pl. 59, figs. $1,5,8$.

Type specimens.-Lectotype, here selected, $\mathrm{MCZ}$ 8502 (pl. 5, figs. 5, 6; Davis, 1887, pl. 24, fig. 2; 
Stumm, 1965, pl. 59, fig. 1) ; paralectotype, MCZ 8501 (Davis, 1887, pl. 24, fig. 1).

Description.-Like $B$, arbor except that known branch diameters are 10 to $20 \mathrm{~mm}$ and corallite diameters in thin-walled zone are $0.7 \mathrm{~mm}$ or less; tabulae are uncommon. Specimen MCZ 8501 (pl. 1, figs. 9, 10) shows the attachment scar of the corallum. No holotheca is preserved, but the "trunk" thickening and the broad expansion layers may be typical for this type of growth.

\section{Bractea impedita (Davis)}

1887 [part] Favosites radiciformis of Davis (not Rominger), pl. 20, fig. 3 (not figs. 1, 2).

1887 Favosites impeditus Davis, pl. 24, figs. 4, 5.

1950 Thamnopora? impeditus Davis. Stumm, card 385.

1965 Favosites impeditus Davis. Stumm, p. 63, pl. 70, figs. 7,9 .

Type specimens.-Lectotype, here selected, MCZ 8690 (Davis, 1887, pl. 24, fig. 4; Stumm, 1965, pl. 70, fig. 9). Paralectotype, MCZ 8691 (Davis, 1887, pl. 24, fig. 5). Hypotype of F. radiciformis of Davis MCZ 8597 (Davis, 1887, pl. 20, fig. 3; Stumm, 1965, pl. 70, fig. 7).

Description.-Like $B$. frutex with small branch diameters and small corallite diameters in axial zone. The three studied specimens differ in having less pronounced dimorphism at colony surface (see cited illustrations) and much less wall thickening in outer zone. Squamulae abundant in both zones; tabulae rare or lacking.

\section{REFERENCES CITED}

Billings, Elkanah, 1858a, New species of fossils from the Silurian rocks of Canada: Canada Geol. Survey, Rept. Prog. for 1857, p. 256-345.

1858b, New genera and species of fossils from the Silurian and Devonian formations of Canada: Canadian Naturalist, v. 3, p. 419-444.

- 1859, On the fossil corals of the Devonian rocks of Canada West: Canadian Jour., new ser., v. 4, p. 97140 (reprint edition paged 1-44).

- 1863, in Logan, W. E., Report on the geology of Canada: Canada Geol. Survey, Rept. Prog. to 1863, $983 \mathrm{p}$.

Coates, A. G., and Oliver, W. A., Jr., 1973, Coloniality in zoantharian corals, in Boardman, R. S., Cheetham, A. H., and Oliver, W. A., Jr., eds., Animal Colonies-Their development and function through time: Stroudsburg, Pa., Dowden, Hutchison and Ross, Inc., p. 3-27.

Davis, W. J., 1887, Kentucky fossil corals, a monograph of the fossil corals of the Silurian and Devonian rocks of Kentucky: Kentucky Geol. Survey, pt. 2 (only part published), 139 pls. and expl.

Dubatolov, V. N., 1969, [Tabulates and biostratigraphy of the Lower Devonian of the north-east USSR]: Akad. Nauk SSSR Sibirsk. Otdeleniye Inst. Geologii i Geofiziki Trudy, v. 70, $179 \mathrm{p}$.
1971, [Taxonomic significance of the microstructure of the skeletal parts of Tabulata], in Dubatolov, V. N., ed., [Papers of 2d All-Union symposium on fossil corals of the USSR], v. 1: Izdatelstov Nauka, Mascow (Akad. Nauk SSSR Sibirsk. Otdeleniye Inst. Geologii i Geofiziki-Postoyannaya Komissiya po Izucheniyu Iskopayemykh Korallov SSSR), p. 12-33.

Fenton, C. L., and Fenton, M. A., 1936, The "tabulate" corals of Hall's "Illustrations of Devonian Fossils": Carnegie Mus. Annals, v. 25, art. 5, p. 17-58.

Flower, R. H., 1961, Montoya and related colonial corals: New Mexico Bur. Mines and Mineral Resources, Mem. $7,229 \mathrm{p}$.

Lambe, L. M., 1899, The Madreporaria Perforata and the Alcyonaria, in A revision of the genera and species of Canadian Palaeozoic corals: Canada Geol. Survey, Contr. Canadian Palaeontology, v. 4, pt. 1, p. 1-96.

Lindström, Gustav, 1899, Remarks on the Heliolitidae: Kongl. Svensk. Vetensk.-Akad. Handl., v. 32, p. 1-140.

Nicholson, H. A., 1874, Report upon the palaeontology of the Province of Ontario: Toronto, $133 \mathrm{p}$.

1879 , On the structure and affities of the "Tabulate corals" of the Palaeozoic period: Edinburgh and London, 342 p.

1881, On the structure and affinities of the genus Monticulipora and its subgenera: Edinburgh, 240 p.

Oekentorp, Klemens, 1972 Sekundärstrukturen bei paläozoischen Madreporaria: Münster. Forsch. Geol. Paläont., v. 24 , p. $35-108$.

Oliver, W. A., Jr., 1966, Description of dimorphism in Striatopora flexuosa Hall: Palaeontology, v. 9, pt. 3, p. 448-454.

1973, Devonian coral endemism in eastern North America and its bearing on paleogeography, in Organisms and continents through time: Spec. Papers Palaeontology, no. 12, p. 318-319.

- 1974, Endemism and biogeography of Late Silurian to Middle Devonian rugose corals in eastern North America: Proc., Int. Paleontological Symposium on Corals, Novosibirsk (1971). (In press.)

Quenstedt, F. A., 1881, Petrefactenkunde Deutschlands, VI; Die Röhren- und Sternkorallen: Leipzig, 1,094 p.

Rominger, C. L., 1862, Description of Calamorporae found in the gravel deposits near Ann Arbor, Michigan, with some introductory remarks: Am. Jour. Sci., ser. 2, v. 34, p. $389-400$.

1876, Palaeontology-Fossil corals: Michigan Geol. Survey, v. 3, pt. 2, 161 p.

Ross, M. H., 1953, The Favositidae of the Hamilton Group (Middle Devonian of New York): Buffalo Soc. Nat. Sci. Bull, v. 21, no. 2, p. 32-89.

Sokolov, B. S., 1952, [Paleozoic tabulates of the European part of the USSR; Part 4, Devonian of the Russian Platform and western Urals]: USSR, Vses. Neft. Nauchno-Issled. Geol.-Razved. Inst. Trudy, v. 62, 291 p. - 1955, [Paleozoic tabulates of the European part of the USSR; Introduction]: USSR, Vses. Neft. NauchnoIssled. Geol.-Razved. Inst. Trudy, v. 85, 527 p.

Stumm, E. C., 1949, 1950, Tabulata, Family Favositidae: Unit 1-E, pts. B and C, in Type invertebrate fossils of North America (Devonian): Wagner Free Inst. Sci., Philadelphia, Cards 115-260 (1949), and 261-405 (1950). 
1965, Silurian and Dervonian corals of the Falls of the Ohio: Geol. Soc. America Mem. 93, 184 p. [dated 1964, but published Jan. 27, 1965].

Swann, D. H., 1947, The Favosites alpenensis lineage in the Middle Devonian Traverse Group of Michigan: Michigan Univ. Mus. Paleontology, Contr., v. 6, no. 9, p. 235318.
Tong-dzuy, Thanh, 1966, Nouveaux genre et sous genre chez les Coelenteres tabulatomorphes devoniens du nord Vietnam: Acta Sci. Vietnam, Sect. biol. geogr. et geog., v. 1 , p. 23-32.

Tripp, Karl, 1933, Die Favositen Gotlands: Palaeontographica, v. 79 , pt. A, no. 3-6, p. 75-142. 



\section{INDEX}

[ltalic page numbers indicate both major references and descriptions]

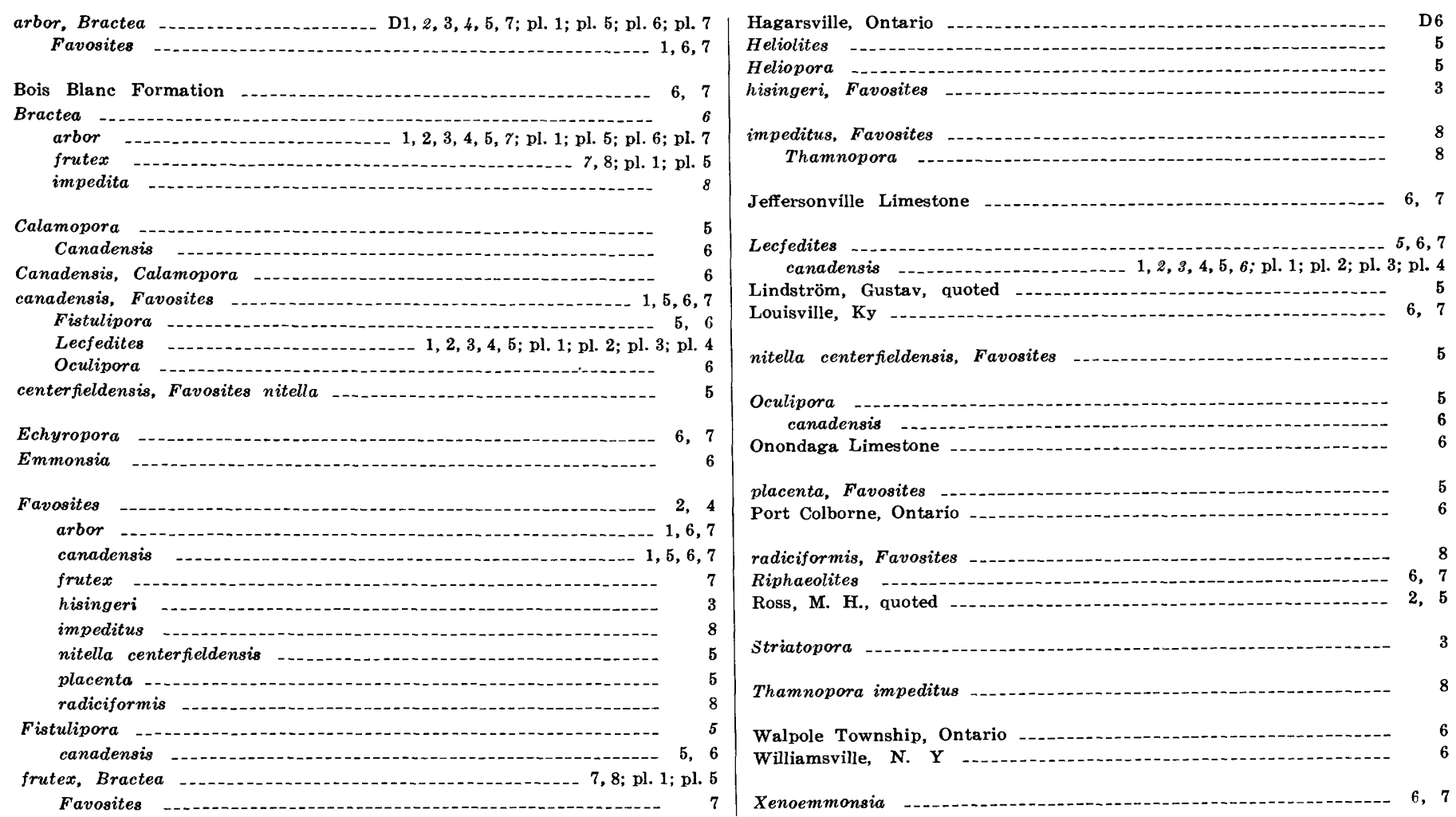





\section{PLATES $1-7$}

Contact photographs of the plates in this report are available, at cost, from U.S.

Geological Survey Library, Federal Center, Denver, Colorado 80225. 


\section{PLATE 1}

Figures 1-4,8. Lecfedites canadensis (Billings) (p. D6).

1,2. Lectotype, GSC 3387. Surface of colony, $\times 1$, and detail, $\times 2$. Near Port Colborne, Ontario.

3,4. MCZ 8518. Part of specimen illustrated by Davis, 1887, pl. 29, fig. 1; $\times 1, \times 2$. Falls of the Ohio, Louisville, Ky.

8. Paralectotype, GSC $3387 \mathrm{~b}$. Possibly the specimen illustrated by Billings, $\times 1$. Near Port Colborne, Ontario.

5-7. Bractea arbor (Davis) (p. D7). Falls of the Ohio, Louisville, Ky.

5. Lectotype, MCZ 8496a. Surface of a part of the branch, $\times 1$.

6, 7. Paralectotype, MCZ $8496 \mathrm{~b}$. Part of surface, $\times 2$, and branching fragment, $\times 1$.

9, 10. Bractea frutex (Davis) (p. D7). Paralectotype, MCZ 8501. Falls of the Ohio, Louisville, Ky. Two views of corallum showing broad base of attachment, $\times 1$. 


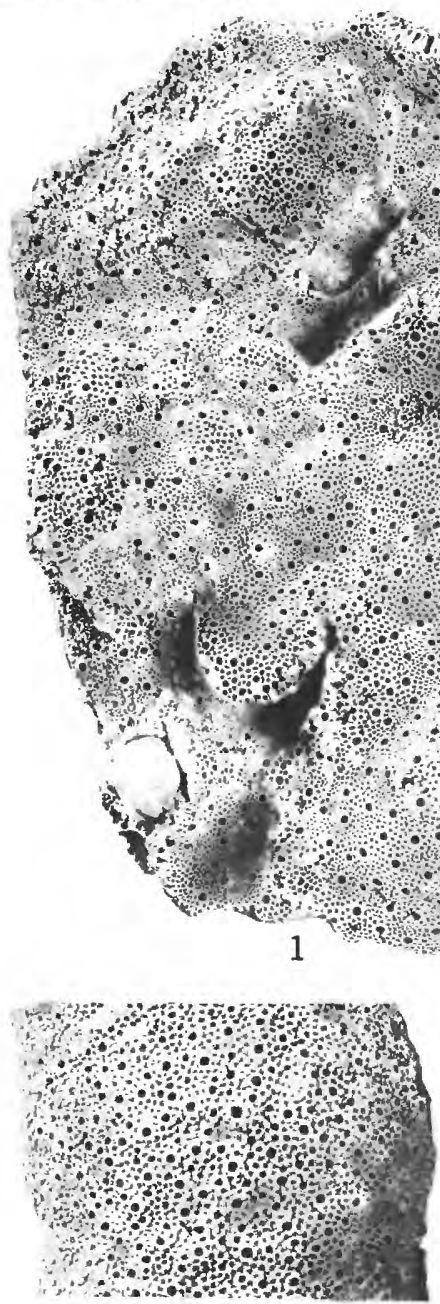

5

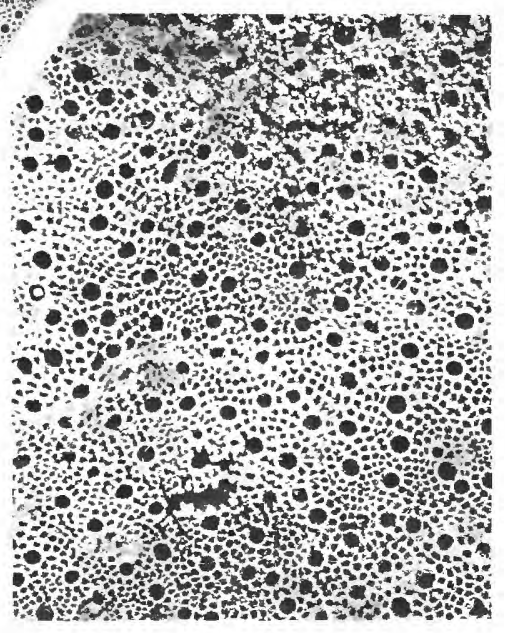

4

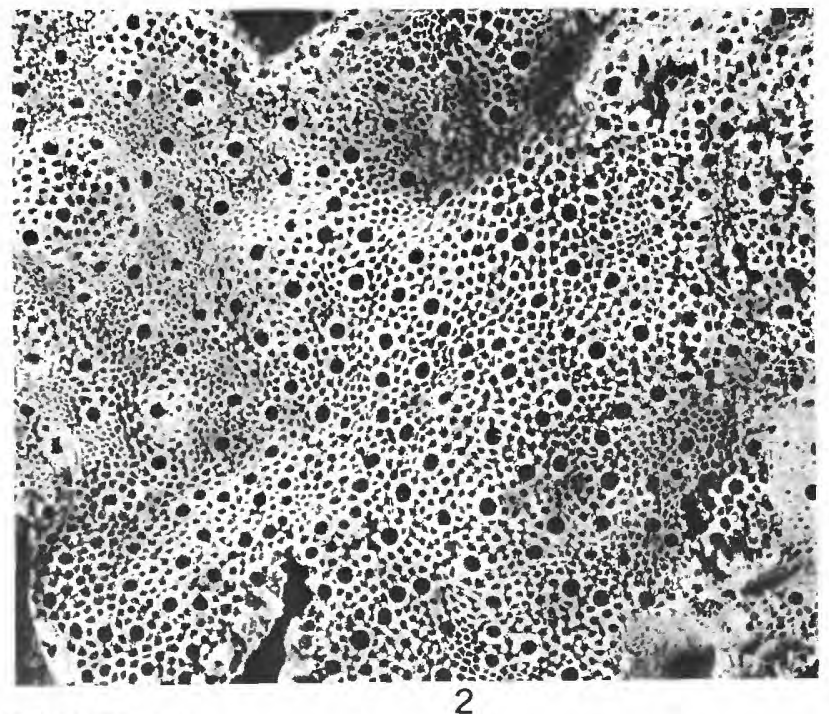
2

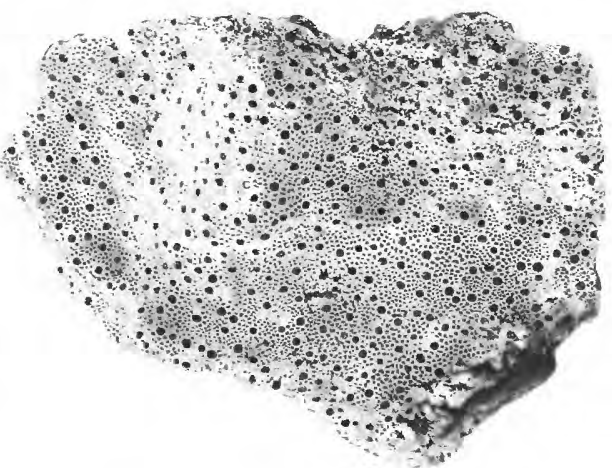

3

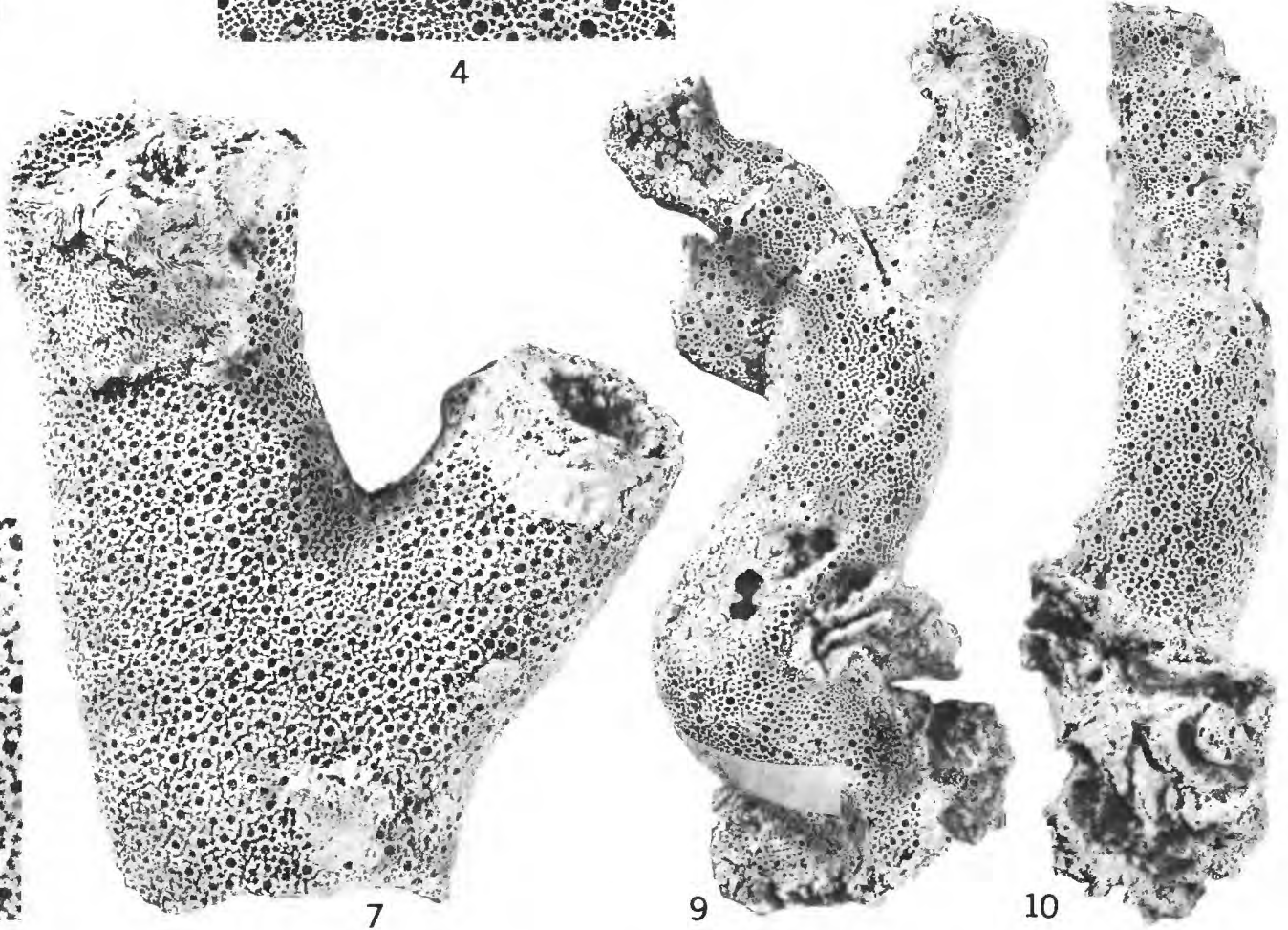




\section{PLATE 2}

Figures 1-6. Leefedites canadensis (Billings) (p. D6). USNM 189924, Williamsville, N.Y.

1-3,6. Longitudinal thin section shown almost entire in figure $3, \times 1 \frac{1}{2}$, and in part in others, $\times 10$, $\times 5, \times 10$.

4,5. Entire transverse thin section, $\times 1 \frac{1}{2}$, and part of same, $\times 5$. 
PROFESSIONAL PAPER 743-D PLATE 2

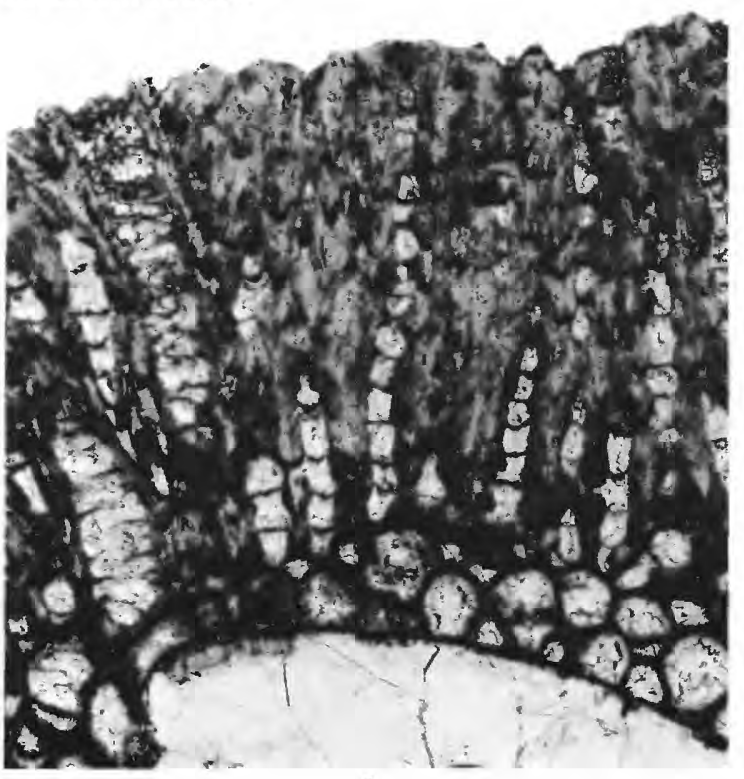

1

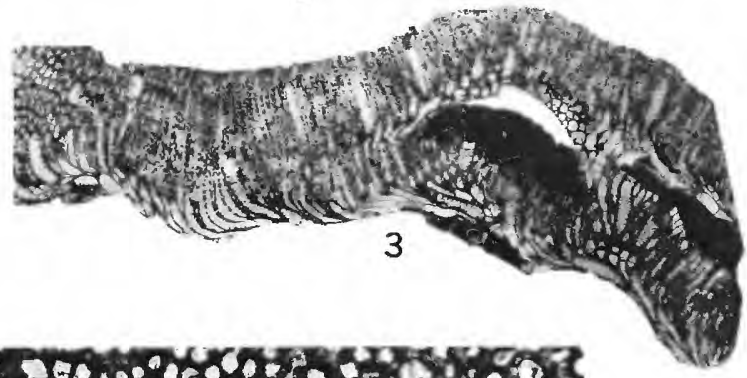

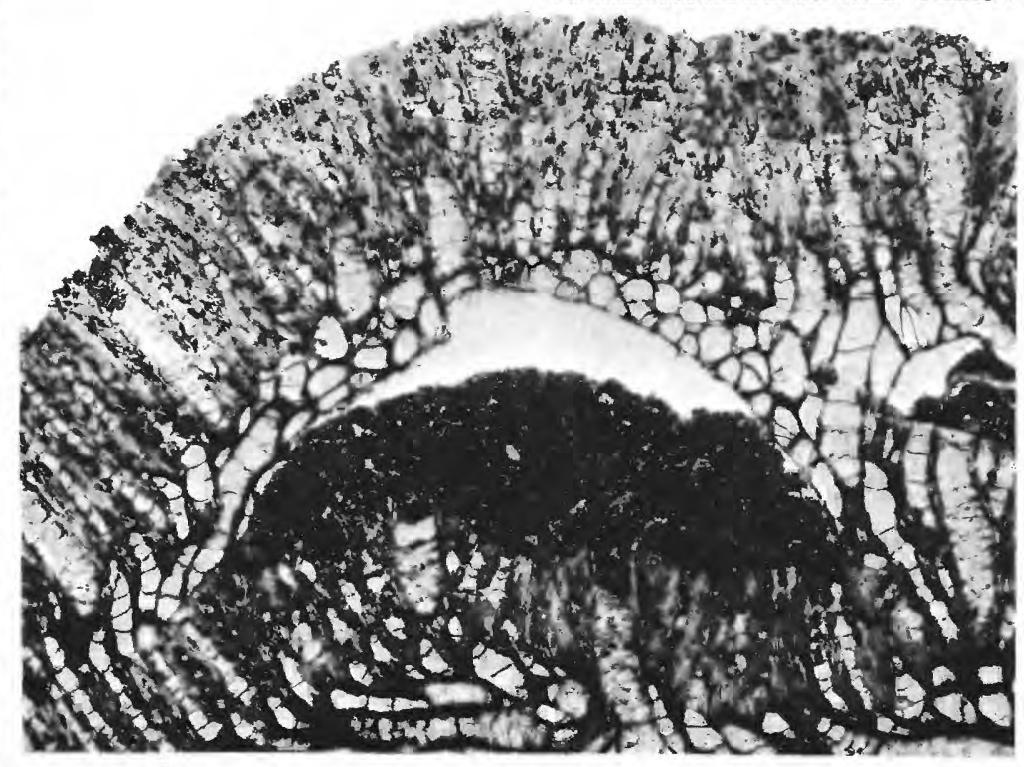

2
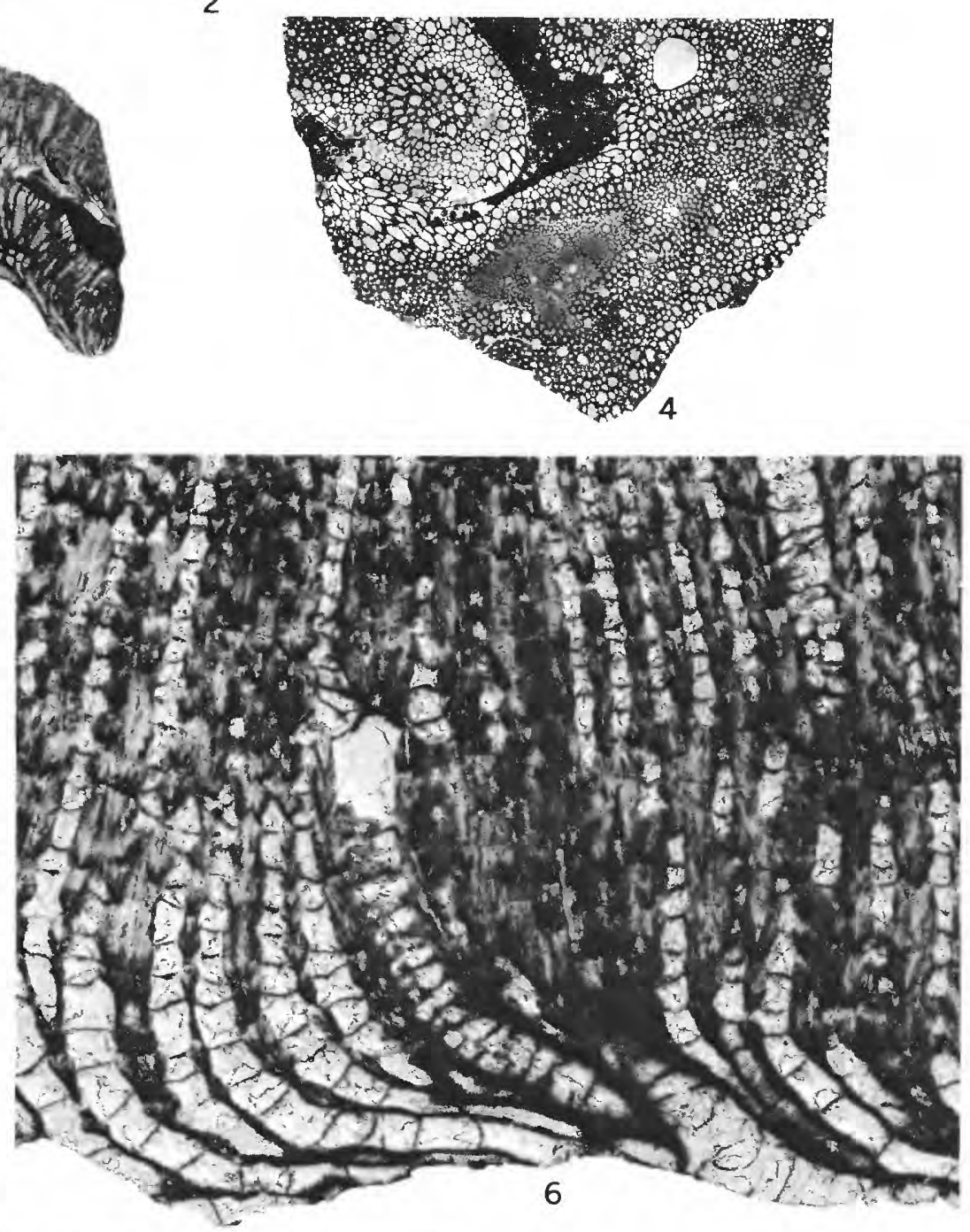


\section{PLATE 3}

FIGURES 1-6. Lecfedites canadensis (Billings) (p. D6).

1,2. USNM 189922. Part of longitudinal thin section, $\times 5, \times 25$. Near Williamsville, N.Y.

3,4. USNM 189928. Longitudinal thin section, $\times 1 \frac{1}{2}$, and part of same, $\times 10$. Falls of the Ohio, Louisville, Ky.

5. USNM 189923. Part of a longitudinal thin section, $\times 10$. Near Williamsville, N. Y.

6. USNM 189925. Part of longitudinal thin section, $X 10$. Near Williamsville, N.Y. 
GEOLOGICAL SURVEY
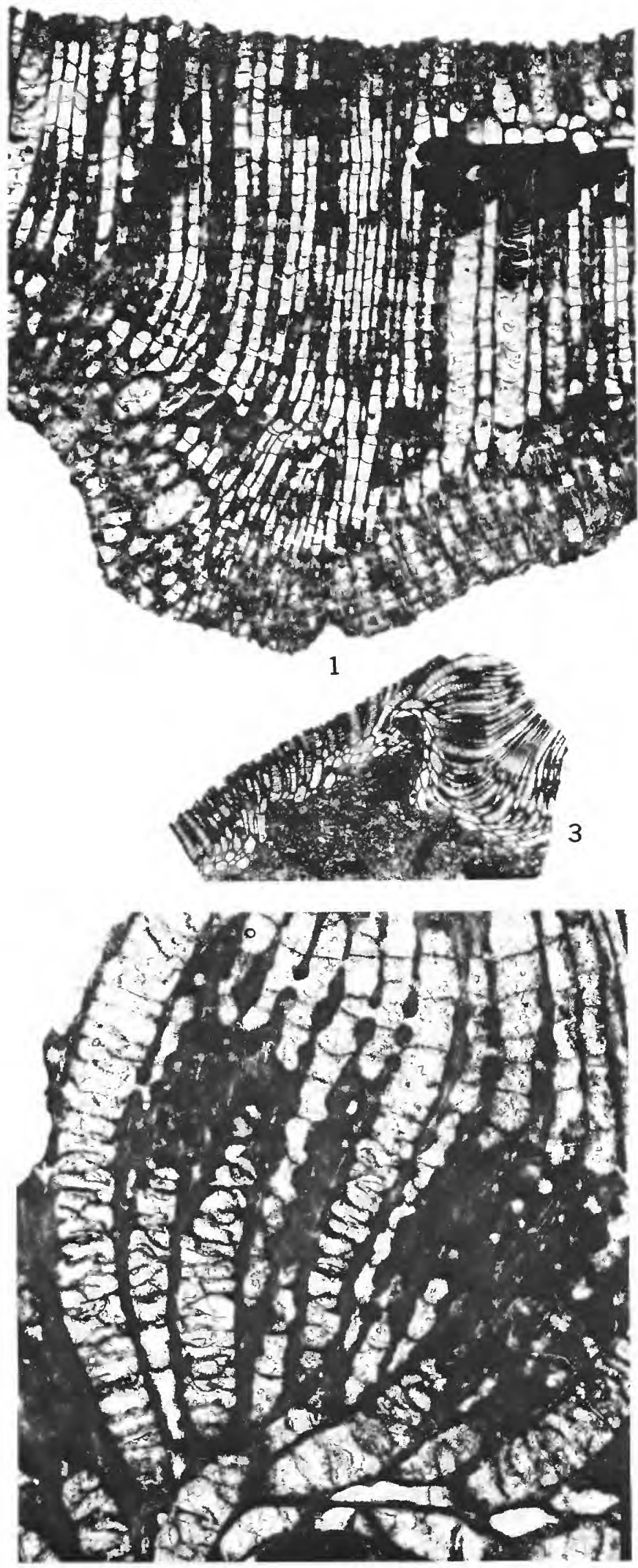

4

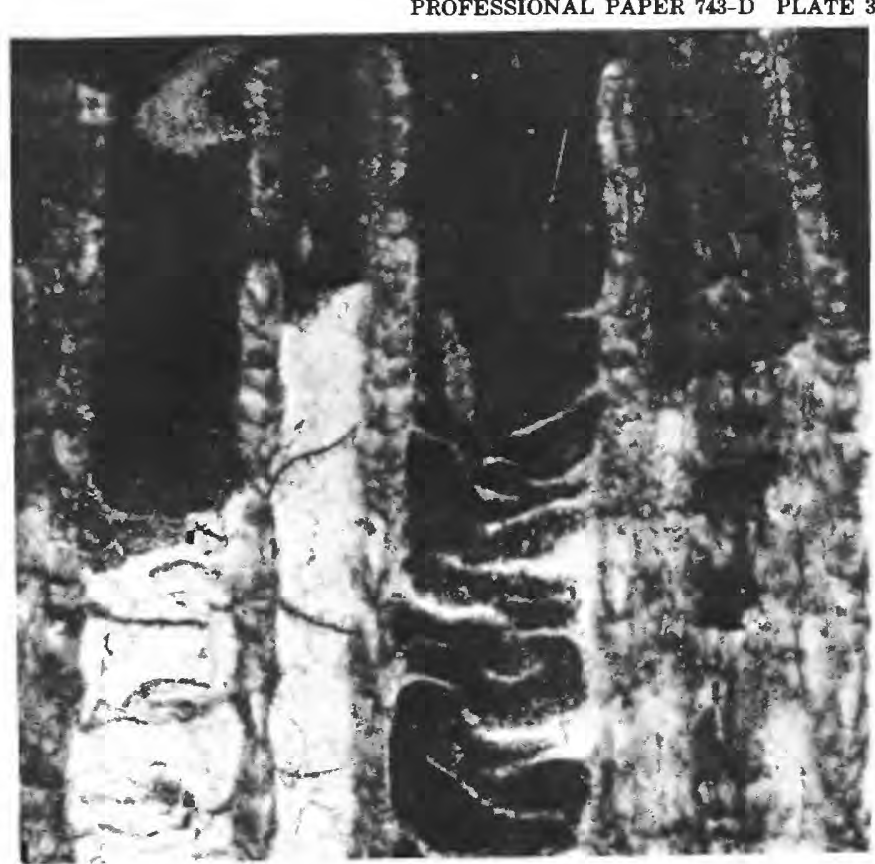

2
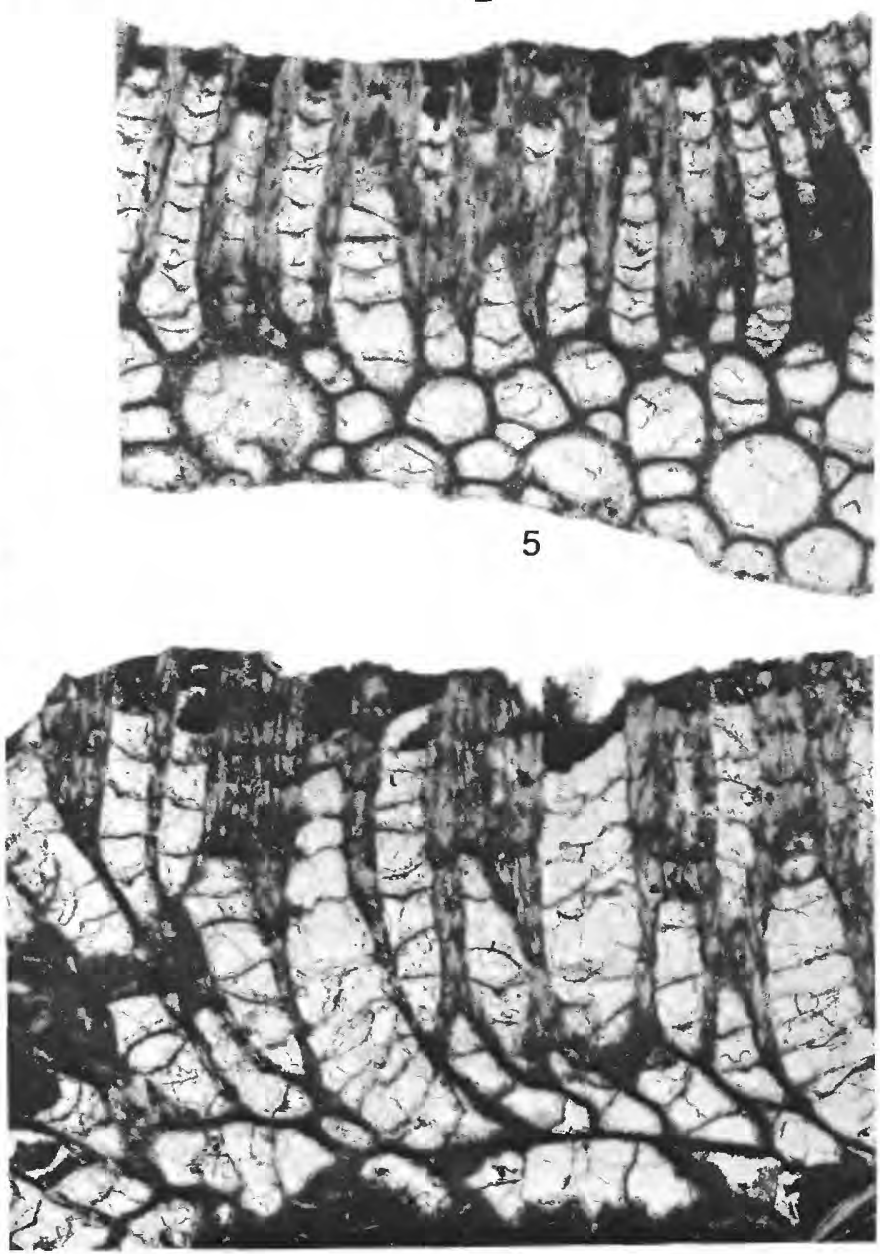

6

LECFEDITES CANADENSIS (BILLINGS) 


\section{PLATE 4}

Figures 1-7. Lecfedites canadensis (Billings) (p. D6). Near Williamsville, N.Y.

1-5. USNM 189926.

1-3. Part of transverse thin section, $\times 25$ and $\times 10$, and complete section, $\times 11 / 2$.

4,5. Part of longitudinal thin section, $\times 5, \times 10$.

6,7. USNM 189927. Details, $\times 25$, of longitudinal and transverse thin sections. Note that original structure within columns (trabeculae) has been destroyed although columns are clearly defined (compare fig. 6 with pl. 3, fig. 2, which shows trabecular structure of columns). 

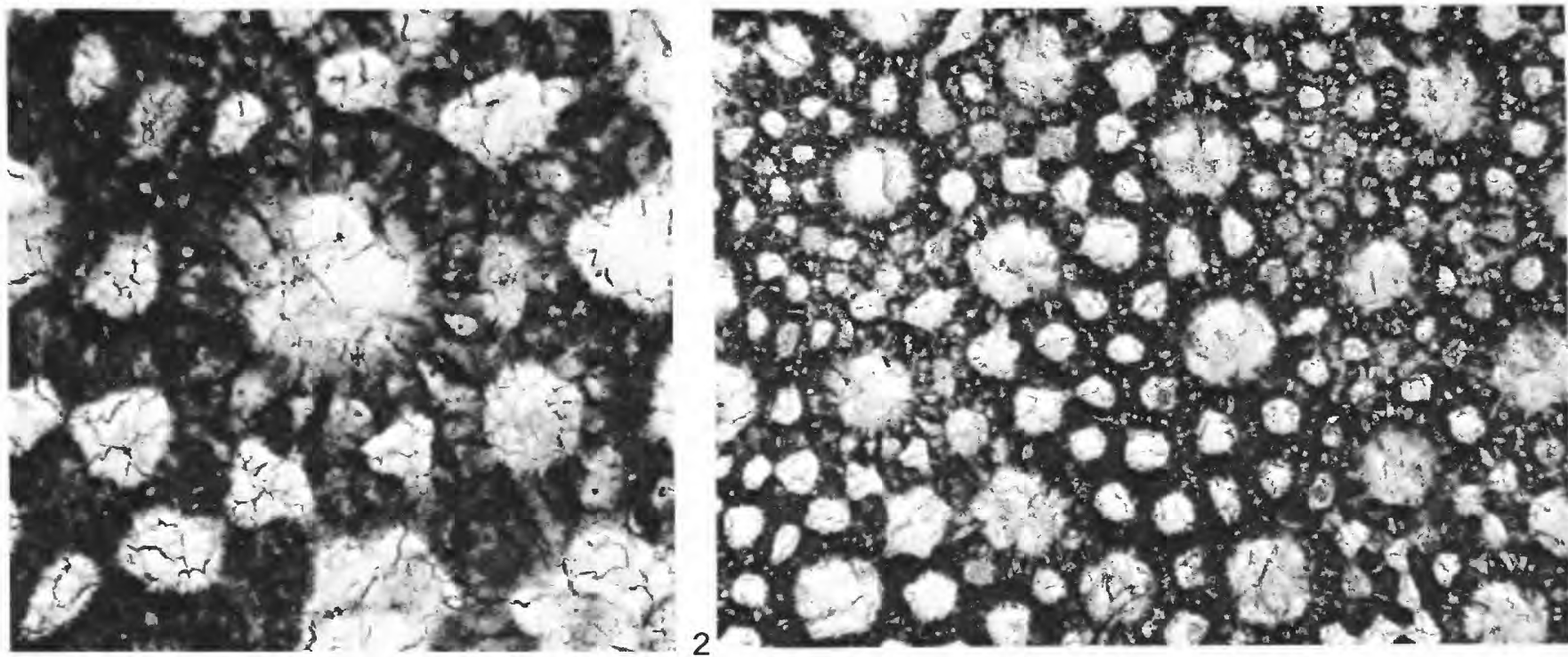

\section{1}

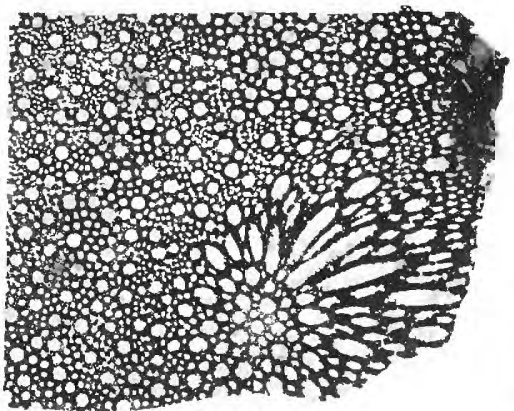

IHUWFI/ 41010\%

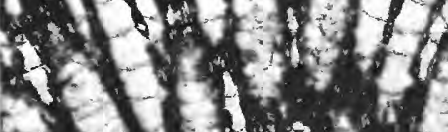

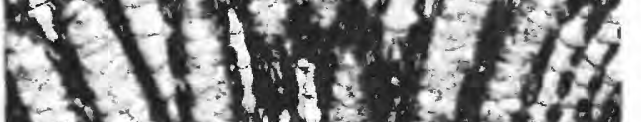

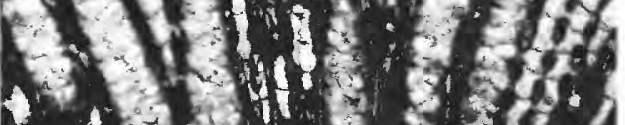

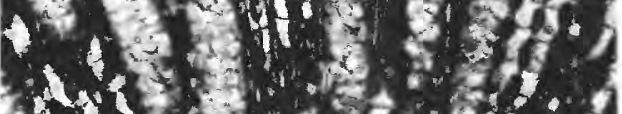

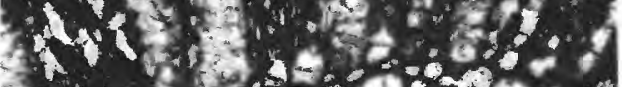
3

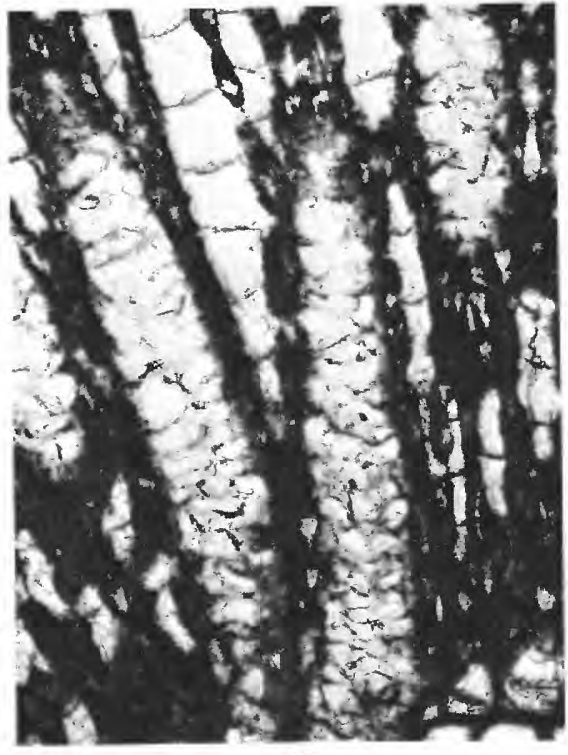
5

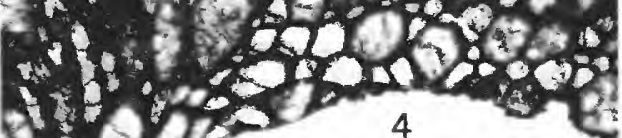

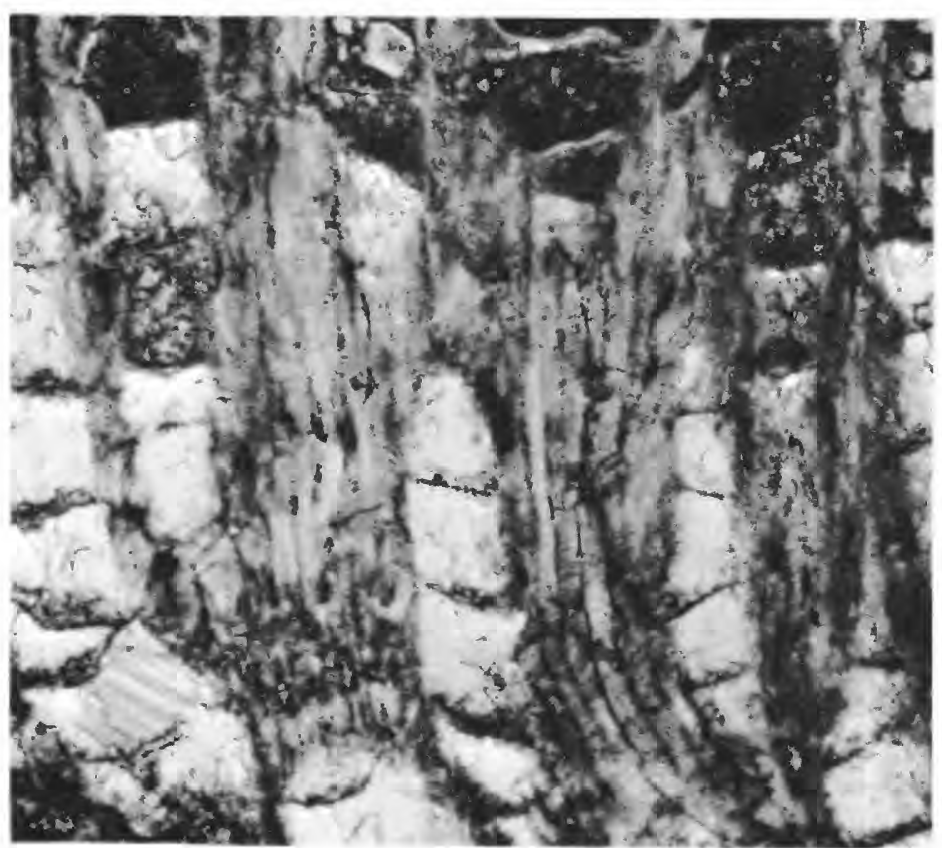

6

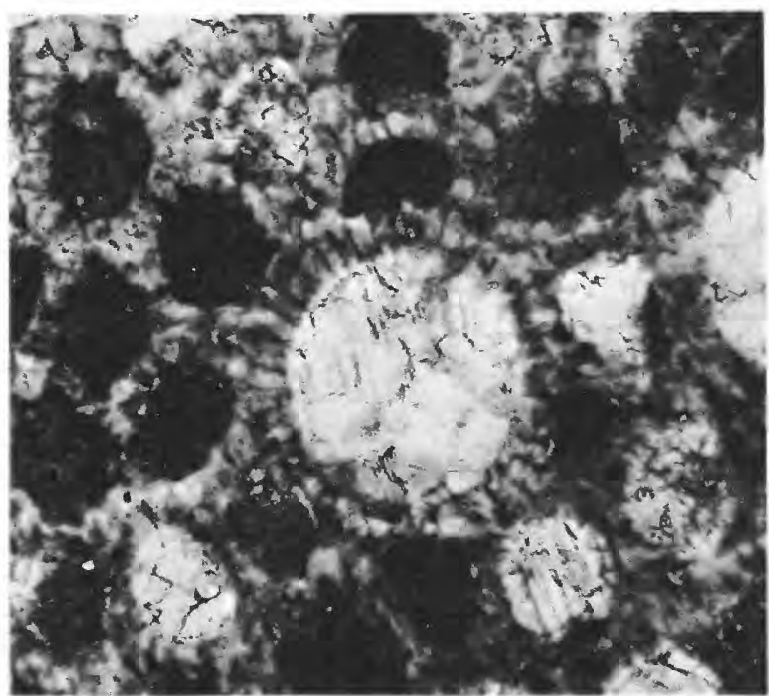

7

LECFEDITES CANADENSIS (BILLINGS) 


\section{PLATE 5}

Figures 1-4. Bractea arbor (Davis) (p. D7).

Lectotype MCZ 8496a. Falls of the Ohio, Louisville, Ky. See also plate 1, figure 5.

1,2. Axial and transverse thin sections, $\times 11 / 2$.

3,4. Parts of the same thin sections, $\times 5$.

5,6. Bractea frutex (Davis) (p. D7).

Lectotype, MCZ 8502. Falls of the Ohio, Louisville, Ky. Transverse and axial thin sections, $\times 5$. 
GEOLOGICAL SURVEY

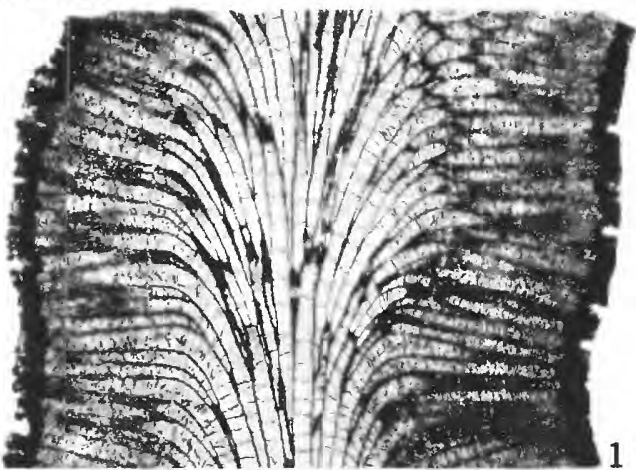

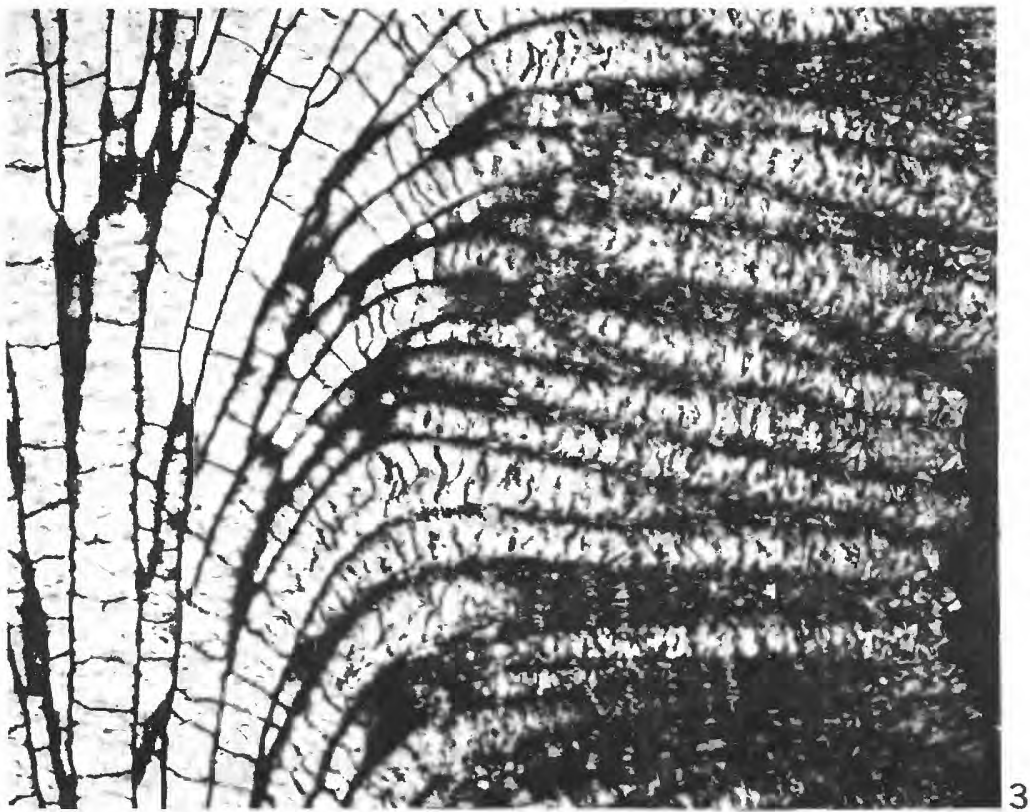

PROFESSIONAL PAPER 743-D PLATE 5

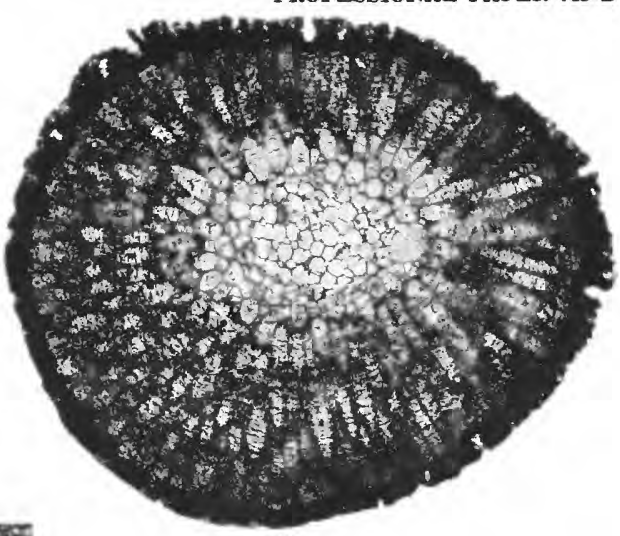

2

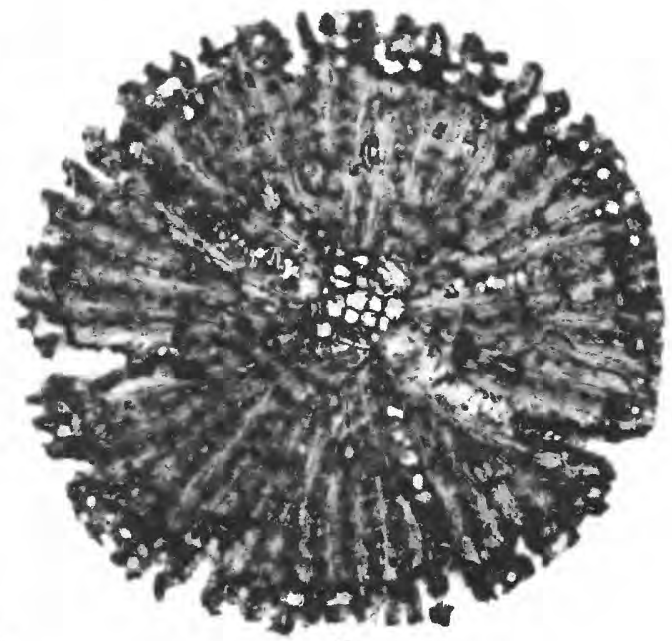

5

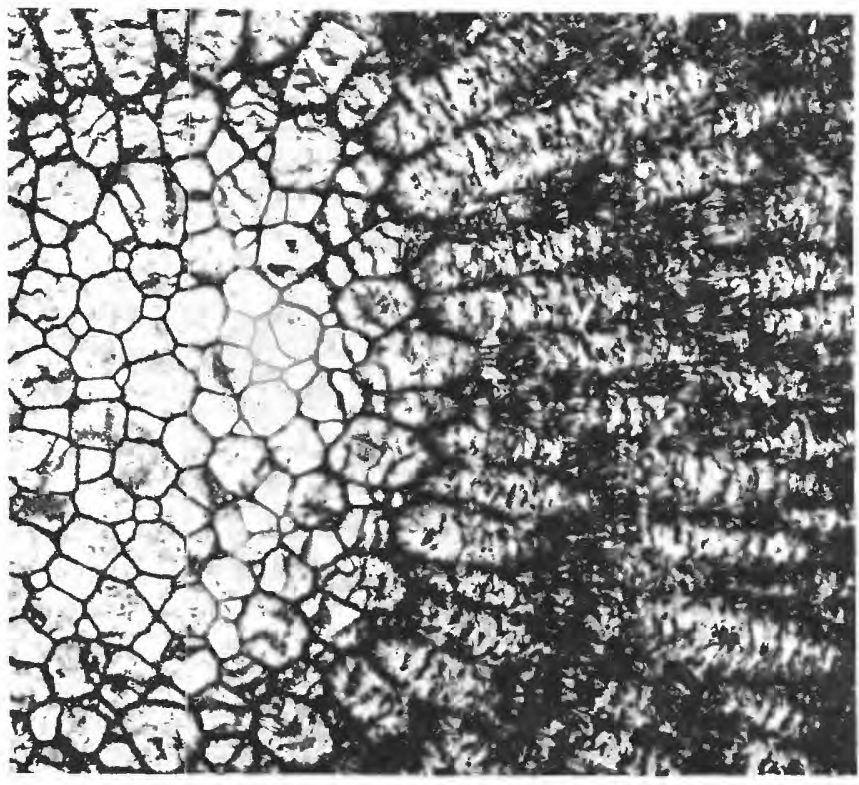

4

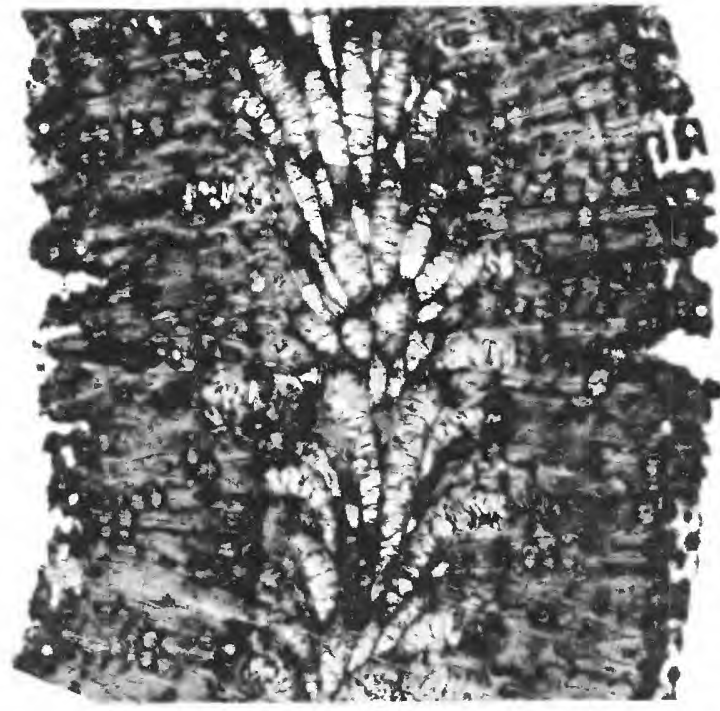

6

BRACTEA ARBOR (DAVIS) AND B. FRUTEX (DAVIS) 


\section{PLATE 6}

FIGURES 1-7. Bractea arbor (Davis! (p. D7).

USNM 189929. Falls of the Ohio, Louisville, Ky. Photographs on plate 7 are of same specimen.

1,2,5. Axial thin section and parts of same section, $\times 5, \times 1 \frac{1}{2}, \times 10$.

3. Outer tangential thin section, $\times 25$. See also plate 7 .

4,7. Transverse thin section and part of same section, $\times 1 \frac{1 / 2}{2} \times 5$.

6. Inner tangential thin section, $\times 25$. See also plate 7 . 

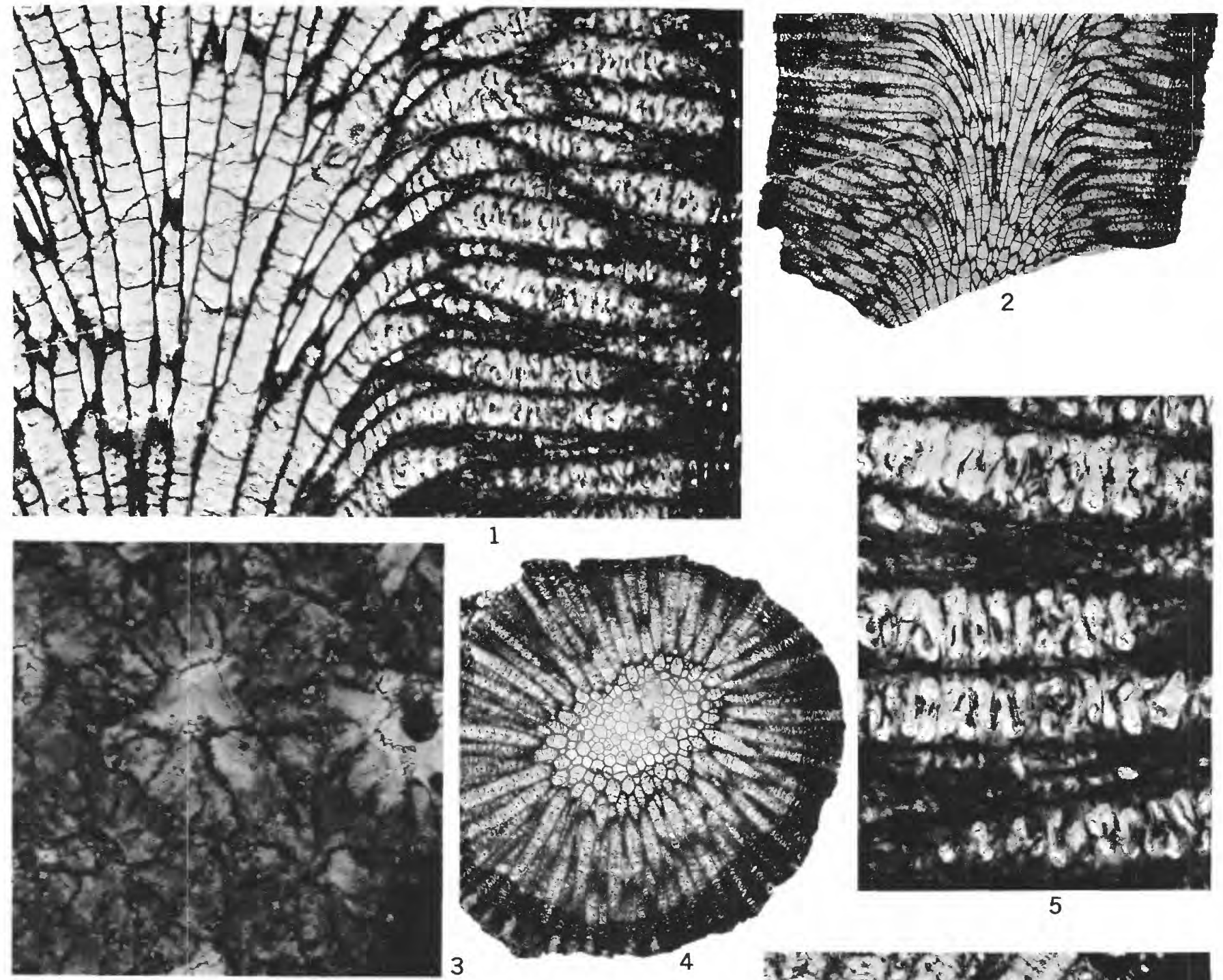

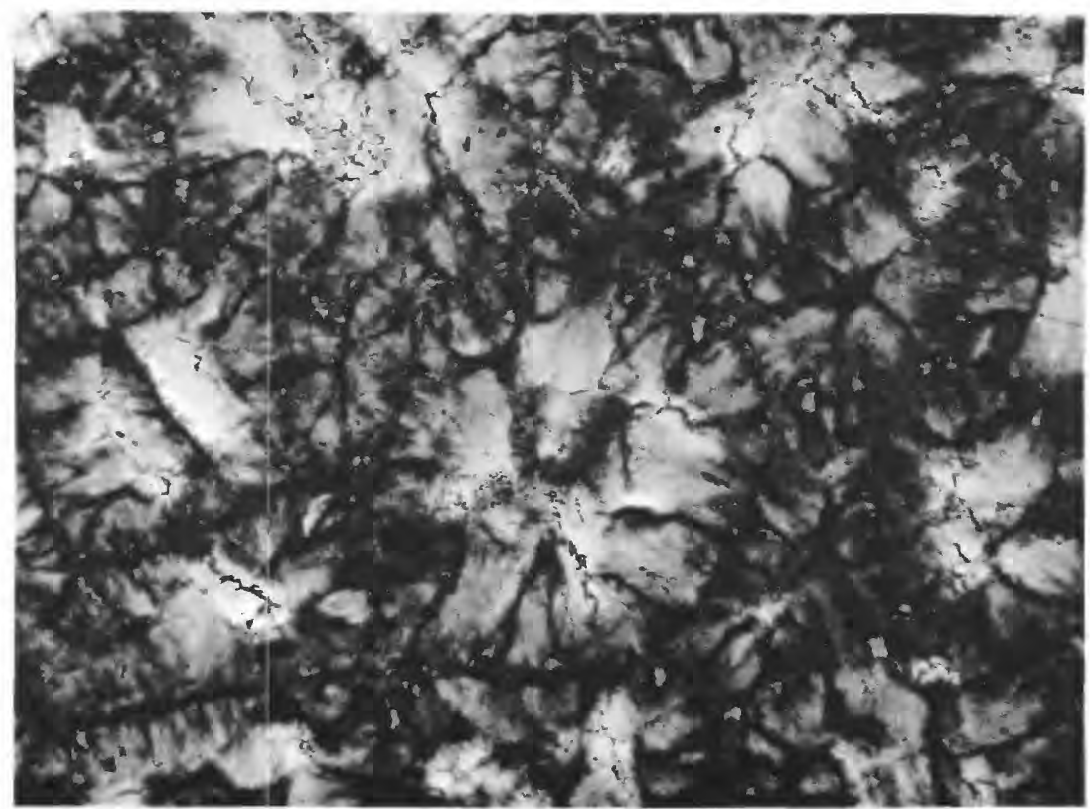

6

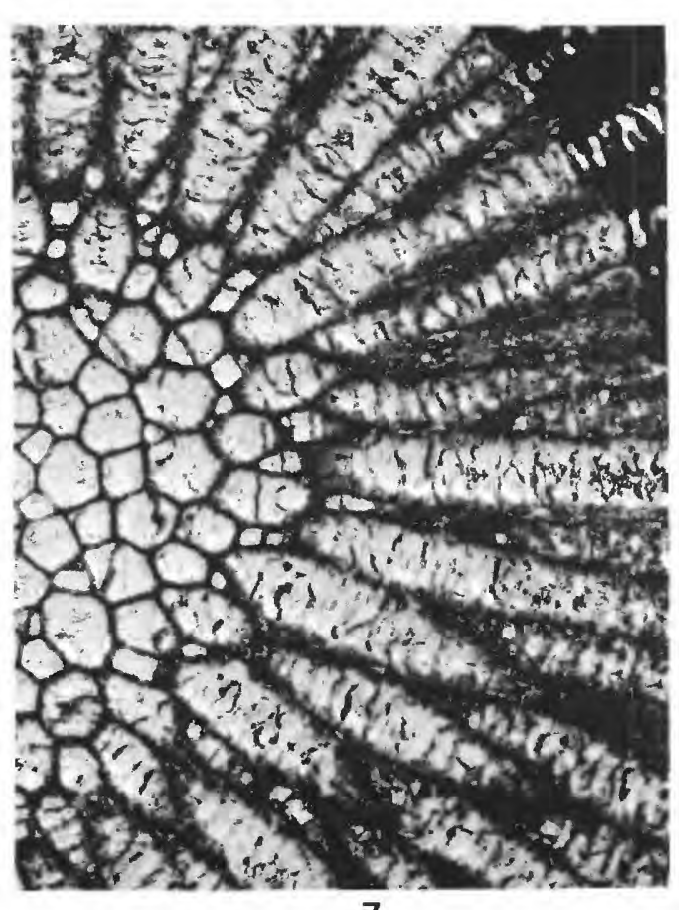
7 


\section{PLATE 7}

Figures 1-7. Bractea arbor (Davis) (p. D7).

USNM 189929. Falls of the Ohio, Louisville, Ky. Tangential thin sections taken parallel to the axial section (pl. 6, fig. 2) at a distance of approximately $12 \mathrm{~mm}$ (inner) and $16 \mathrm{~mm}$ (outer). See also plate 6.

1-4. Inner tangential section, $\times 1 \frac{1}{2}$, and parts of same section, $\times 5, \times 10, \times 25$.

5-7. Parts of outer tangential section, $\times 5, \times 10, \times 25$. 


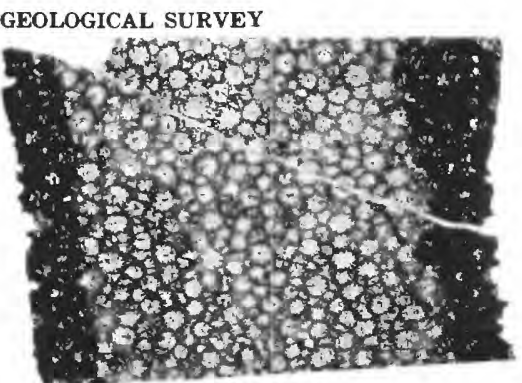

1

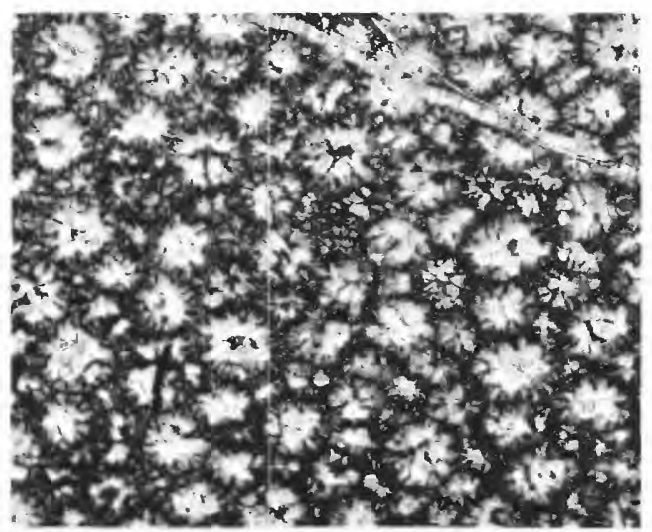

2
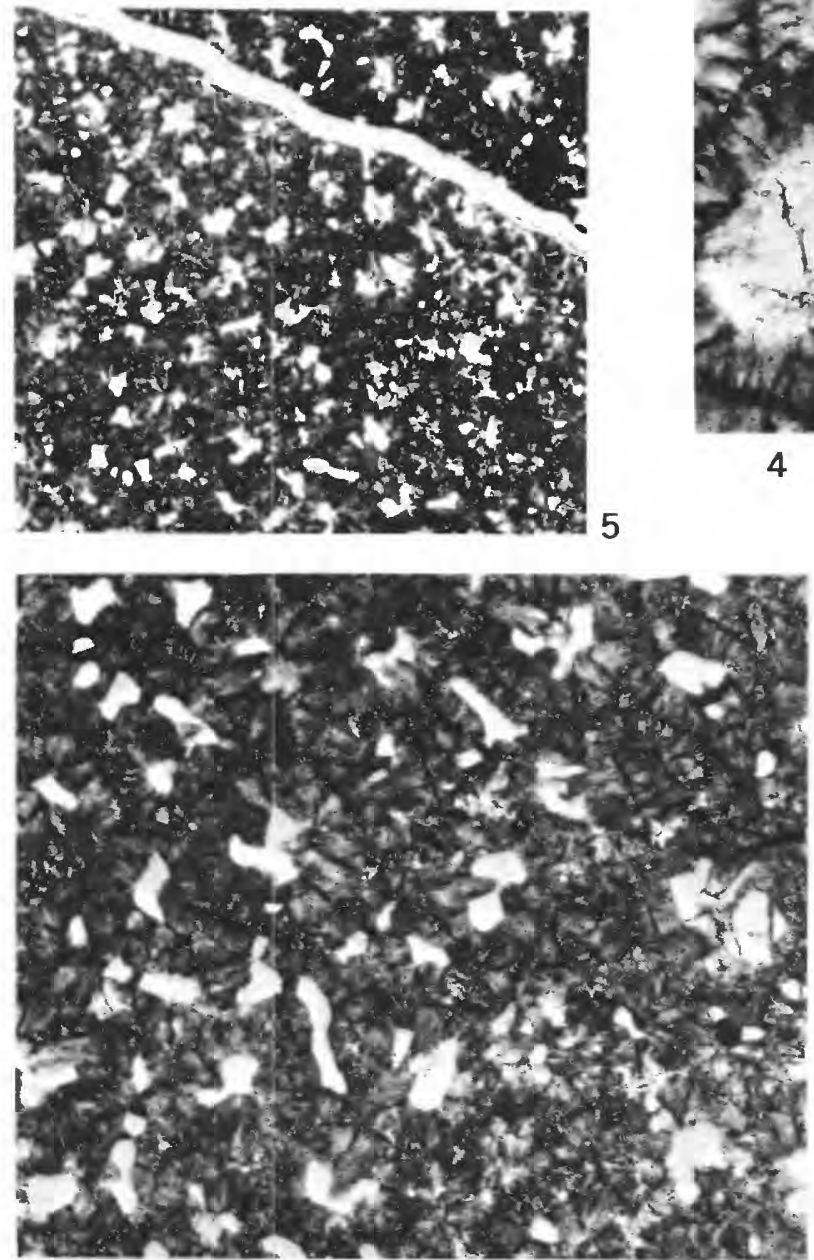

4
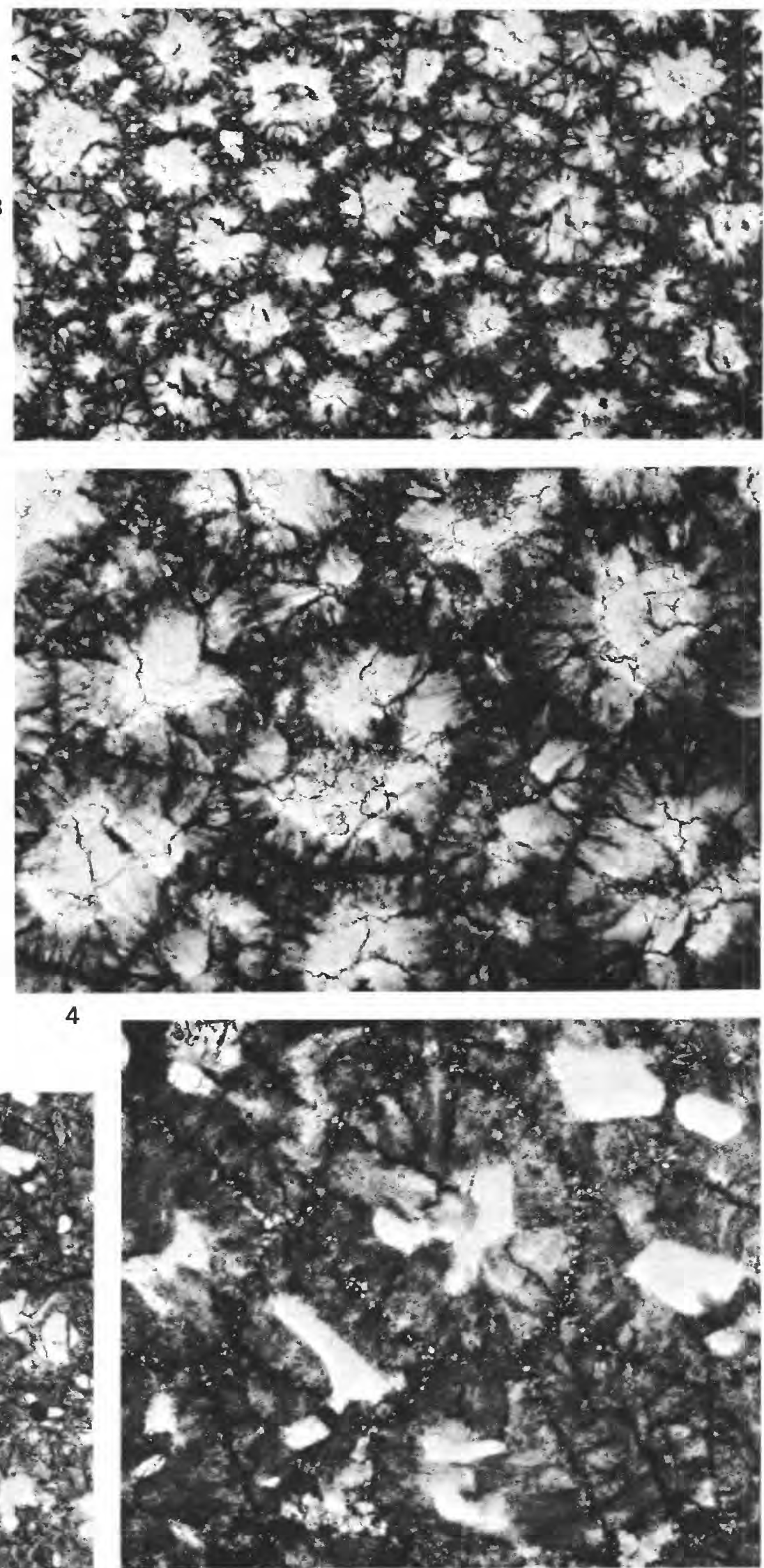

7 